\title{
The role of urban forests in sustainable tourism development: $A$ case study of Savannah, GA
}

\author{
Stacy L. Casinelli \\ West Virginia University
}

Follow this and additional works at: https://researchrepository.wvu.edu/etd

\section{Recommended Citation}

Casinelli, Stacy L., "The role of urban forests in sustainable tourism development: A case study of Savannah, GA" (2009). Graduate Theses, Dissertations, and Problem Reports. 2911.

https://researchrepository.wvu.edu/etd/2911

This Thesis is protected by copyright and/or related rights. It has been brought to you by the The Research Repository @ WVU with permission from the rights-holder(s). You are free to use this Thesis in any way that is permitted by the copyright and related rights legislation that applies to your use. For other uses you must obtain permission from the rights-holder(s) directly, unless additional rights are indicated by a Creative Commons license in the record and/ or on the work itself. This Thesis has been accepted for inclusion in WVU Graduate Theses, Dissertations, and Problem Reports collection by an authorized administrator of The Research Repository @ WVU. For more information, please contact researchrepository@mail.wvu.edu. 


\title{
The Role of Urban Forests in Sustainable Tourism Development: A Case Study of Savannah, GA
}

\author{
Stacy L. Casinelli \\ Thesis submitted to the \\ Davis College of Agriculture, Natural Resources \& Design \\ at West Virginia University \\ in partial fulfillment of the requirements \\ for the degree of \\ Master of Science \\ in \\ Recreation, Parks, and Tourism Resources \\ Chad Pierskalla, Ph.D., Chair \\ Jinyang Deng, Ph.D. \\ David Smaldone, Ph.D.
}

Recreation, Parks, and Tourism Resources Program

Division of Forestry and Natural Resources

Morgantown, West Virginia

2009

Keywords: Sustainable Development, Urban Forestry, Urban Tourism, Aesthetics 


\section{ABSTRACT \\ The Role of Urban Forestry in Sustainable Tourism Development: A Case Study of Savannah, Georgia}

\section{Stacy L. Casinelli}

The purpose of this study was to identify a range of stakeholder (tourism providers, resource managers, elected officials, tour operators and tourists) perceptions, issues and concerns of Savannah, Georgia's, urban forests to help develop opportunities for the growing sustainable tourism industry. Stakeholder interviews were conducted using an open ended, semi-structured questionnaire. Based on the three dimensions and the scope of sustainable development, the themes, trends and patterns that emerged were utilized to assess the current issues facing Savannah's urban forest. Through content data analysis, four overarching themes surfaced: development, preservation, balance, and diversity. The results of this study indicate a strong connection between urban forestry and sustainable tourism development. 


\section{ACKNOWLEDGEMENTS}

First I would like to thank my committee members for all your knowledge and support throughout the thesis writing process. I would like to thank my graduate advisor and committee chair, Dr. Chad Pierskalla, for all your help and guidance through graduate school and completing my thesis.

I would like to thank Dr. Jinyang Deng, who was awarded funding by the USDA Forest Service/National Urban and Community Forestry Advisory Council to make this research possible (Award Number: 07-DG-11420004-030). Thank you for allowing me the opportunity to join you on your first trip to Savannah, which in turn led to further interest in this study and eventually my thesis subject.

I also want to thank Dr. Dave Smaldone for all your guidance and feedback, especially when choosing classes and analyzing data; and to my fellow graduate students, Candace and Maddy, for our lunch time conversations and reinforcing the fact that I could finish this thesis and Sandy and Kate for breaking down qualitative data analysis. I sincerely appreciate all your input.

In addition, I would like to thank all of the stakeholders who contributed to the interview sessions and email questionnaires. I greatly appreciate your time and participation. Without the wealth of knowledge you all provided, this study would not have been possible.

Finally I would like to thank my fiancé, Jerry, my parents, Guy and Sandy, my sister and brother in law, Jamie and Jason, and all my friends for your love, support and encouragement throughout my two years at WVU. I would not have made it without you. Also to my nephew, little Guy, your sweet little face kept me smiling. I love you all. 


\section{TABLE OF CONTENTS}

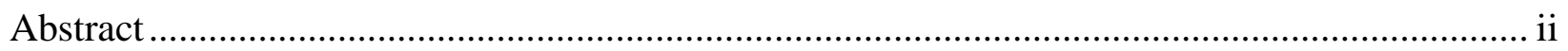

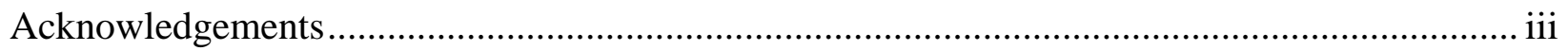

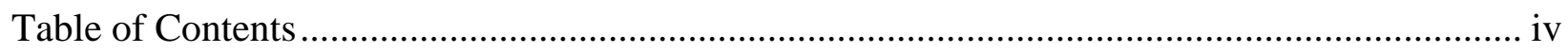

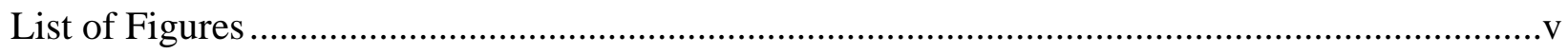

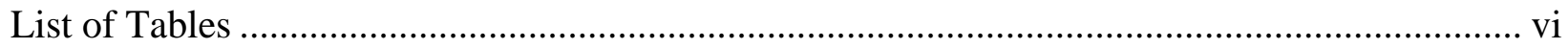

Chapter 1. Introduction ................................................................................................. 1

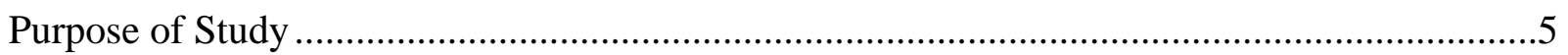

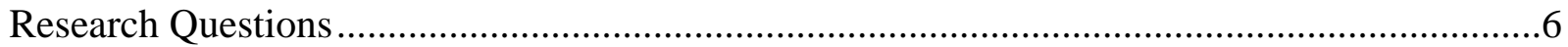

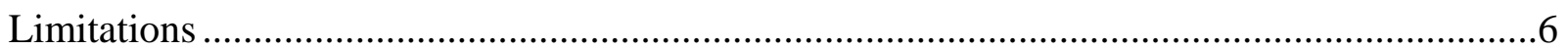

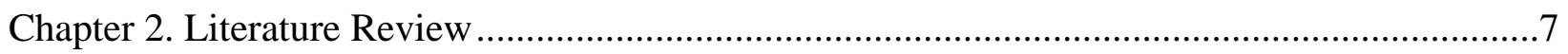

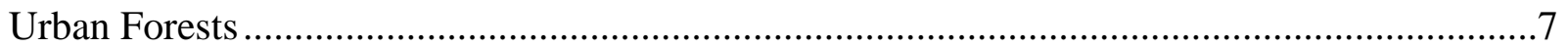

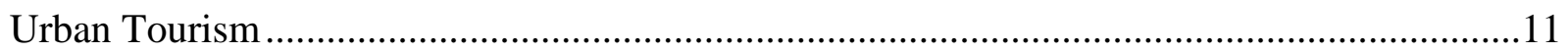

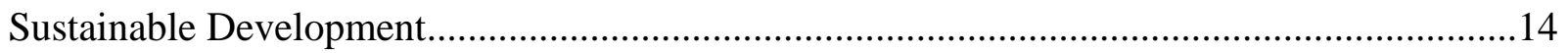

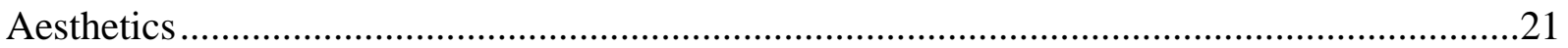

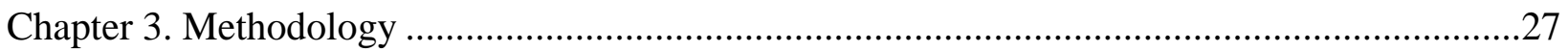

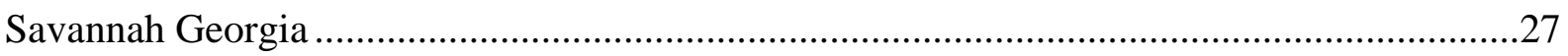

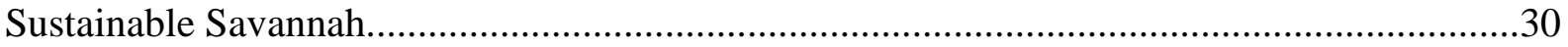

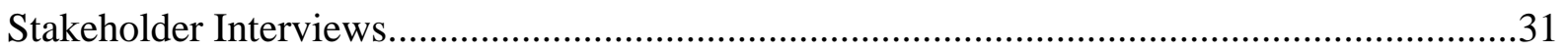

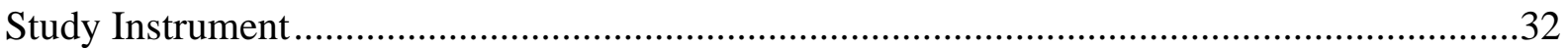

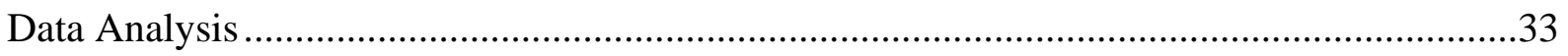

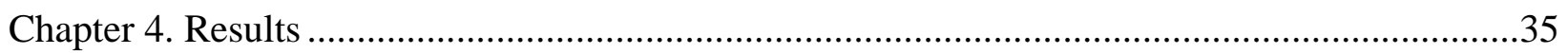

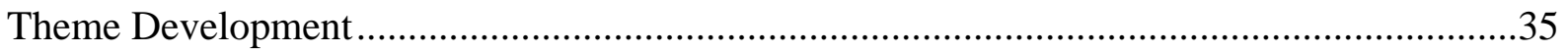

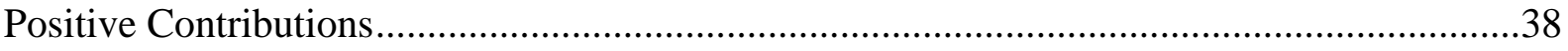

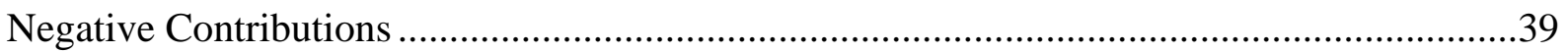

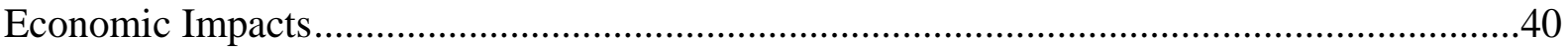

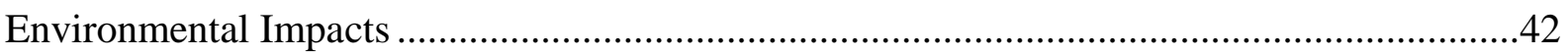

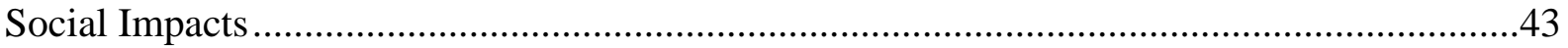

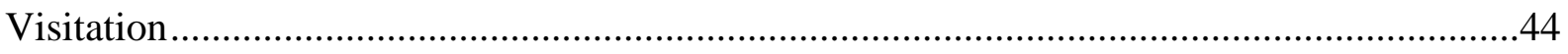

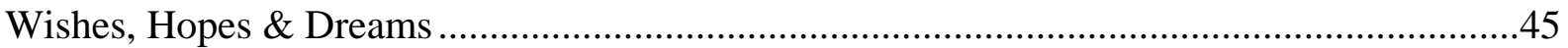

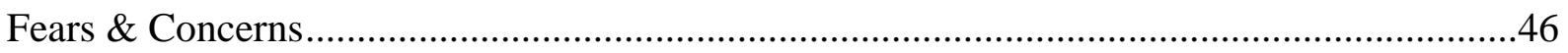

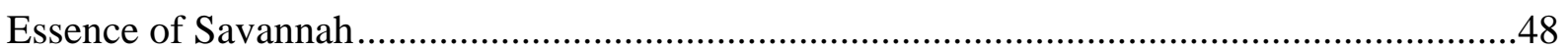




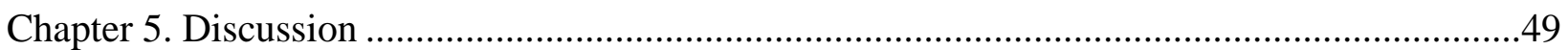

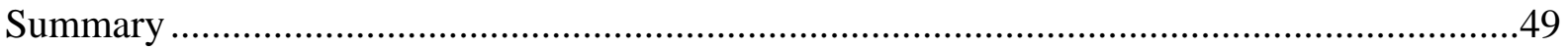

Urban Forestry and Sustainable Tourism Development ..................................................50

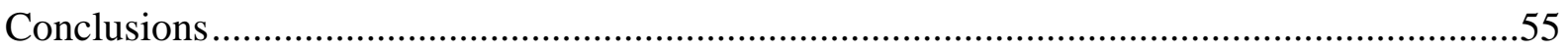

Suggestions for Future Research ................................................................................57

Appendices

Appendix A

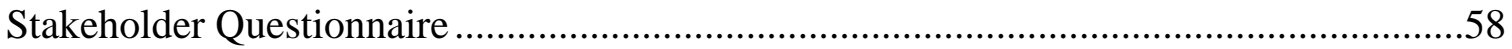

Appendix B

Participant Departments, Offices, and Organizations................................................59

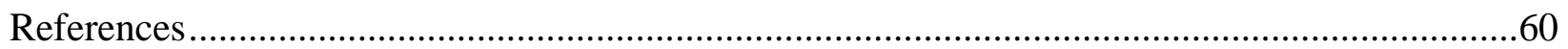




\section{LIST OF FIGURES}

Figure 1. Three Dimensions of Sustainable Development ........................................................4

Figure 2. The Scope of Sustainable Tourism.........................................................................17

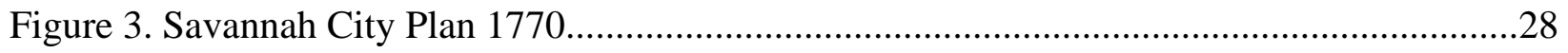

Figure 4. Aerial Photography of Present Day Savannah .....................................................30 


\section{LIST OF TABLES}

Table 1. Differences in Scenic and Ecological Aesthetics

Table 2. Four Main Themes and Trends in Savannah's Urban Forest ... 


\section{Chapter 1. INTRODUCTION}

Urban forestry is the maintenance and management of urban forests in order to preserve the resources that promote environmental, sociological, economic, and aesthetic benefits. Urban forests not only include all the trees, wildlife, watersheds and vegetation surrounding our communities, but they encompass the roadways, the open spaces, parks, residential yards and the undeveloped land within the local boundaries. According to Konijnendijk (2008), city forests have not only played important economic and environmental roles, but these forests have also attributed to many cultural and social values (p. 189).

Urban and metropolitan areas have grown immensely over the years, creating a growing concern for environmental sustainability. Between 1950 and 1990, metropolitan areas tripled in size, while urban areas doubled in size in the last 20 to 30 years (Dwyer, Nowak, Noble, \& Sisinni, 2000). According to the Society of American Foresters (SAF), there are 70 million acres of urban forests in the United States and 80 percent of the population lives, works, and plays in these areas (SAF, 2002). Therefore it is easy to see that urban forests can be found in the largest cities to the smallest villages.

As the permanent population of urban areas rises, tourism in urban areas also increases. Tourism is one of the largest industries in the world. In 2008, there were over 920 million international tourists' arrivals, which is a $2 \%$ increase from 2007; however, worldwide international tourist arrivals have declined by 7\% between January and August 2009. (World Tourism Organization, WTO, 2009). Urban tourism is one of the many facets of the tourism sector and encompasses a variety of elements. Sports and entertainment, conferences, heritage, cultural and shopping are a few reasons individuals choose metropolitan areas as a tourism destination. According to Law (1993), "large cities are in fact the most important type of tourist 
destination across the world" (Law, 1993, p. 1), yet there are many challenges facing urban tourism development. City resources become overused and start to deteriorate; there is an increase in congestion, which leads to a reduction in the quality of life for residents and the overall experience for visitors (Butler \& Dodds, 2008).

The density and complexity of the urban environment poses many challenges (Pearce, 2001). With the growth of tourism in cities, the importance of urban tourism impacts have been recognized by many academics and planners, but they must still find alternative approaches to absorb the tourism implications (Law, 2001). Urban tourism has the potential for incredible economic growth; however, it carries significant negative social and environmental impacts (Jamieson \& Sunalai, 2002). Understanding the positive and negative impacts is crucial when developing a proposal for urban tourism destinations. Active implementation and management of tourism plans and prompt attention to emerging issues will maximize positive impacts and minimize negative impacts (Kreag, 2001).

Urban tourism can meet visitors' expectations and at the same time make a positive contribution to the development of towns and cities and the well-being of their residents (Galdini, 2007). The idea and practice of sustainable tourism development can help accomplish these objectives. Appropriate tourism policies can minimize the negative impacts of tourism on society and the environment, while maximizing tourism's positive and creative contribution to local economies, the conservation of natural and cultural heritage, the quality of life of hosts and visitors (Notarstefano, 2007). Therefore, urban tourism needs to be carefully planned and managed based on the principles of sustainability.

Sustainability is a complex term that has been defined differently and applied in many different ways. The most common definition and most frequently cited was developed by the 
World Commission of Environment and Development (WCED), also known as the Brundtland Commission. The report defined forest sustainability as:

"Sustainable forestry means managing our forests to meet the needs of the present without compromising the ability of future generations to meet their own needs by practicing a land stewardship ethic which integrates the growing, nurturing and harvesting of trees for useful products with the conservation of soil, air, and water quality, and wildlife and fish habitat” (WCED 1987, p.8).

The National Commission of the Environment also contributed to defining sustainable development:

"Sustainable development mandates that the present generation must not narrow the choices of future generations but must strive to expand them by passing on an environment and an accumulation of resources that will allow its children to live at least as well as, and preferably better than, people today” (National Commission on the Environment 1993, p.2).

The common theme linking the two definitions is the future. Until recently, the behavioral patterns of society could be described as actions or manners that disregarded the environmental future. This may be in part due to the lack of knowledge that relates these behaviors to negative environmental effects or the fact that society is unfamiliar with the proper steps to achieve a "green" future. The increase in the promotion of a "green" environment has made society more aware of the proper steps to take to help minimize environmental damage.

The core of mainstream sustainability thinking has developed into the idea of three dimensions: environmental, social, and economic sustainability (Adams, 2006). In order for a community to grow into a fully sustainable entity, all three principles of sustainable development 
must converge and balance (Figure 1). Therefore, the objective of sustainability is to recognize the intertwined importance of social, economic and environmental imperatives and to find ways of contributing to all of them and strengthen the whole (Kemp, Parto, \& Gibson, 2005).

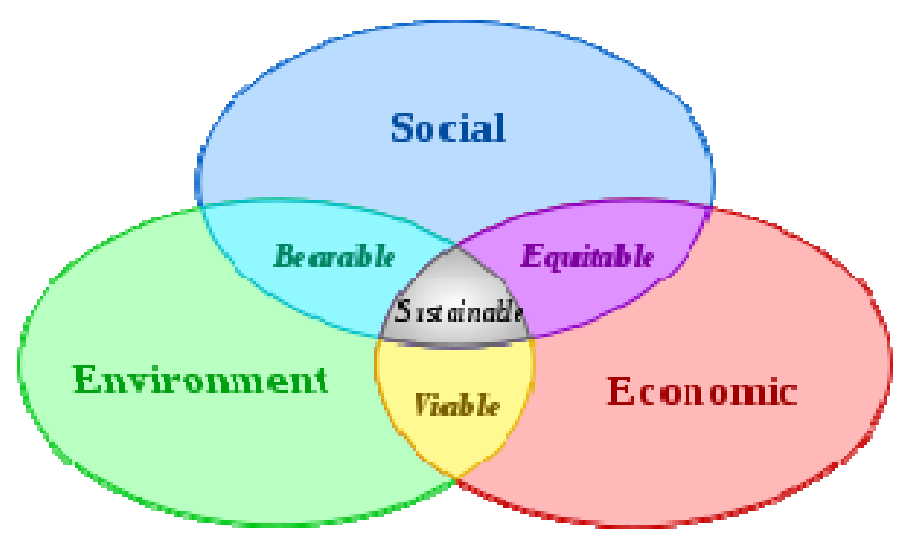

Figure 1. Three dimensions of sustainable development. Adapted from Adams (2006).

The significant outcome of sustaining an urban forest is also to maintain a maximum level of net social, economic, and environmental benefits over time (Clark, Matheny, Cross \& Wake, 1997). Urban forests are an appreciating resource estimated to have a value of nearly $\$ 30$ billion (SAF, 2002). The aesthetic contribution to the landscape is the primary reason for the high value placed on the urban forest. In an urban environment, aesthetic benefits include a more pleasant environment, relief from stress, enhanced feelings and moods, increased enjoyment of everyday life and a stronger connection between people and the environment (Dwyer, McPherson, Schroeder, \& Rowntree, 1992).

In order to maintain the future of the urban forests, sustainable development plans, policies and actions must be established. Although there are several benefits to establishing and maintaining urban forests, trees play the most crucial role in forest sustainability and improving 
the quality of life in urban areas. There are approximately 74.4 billion trees in metropolitan areas and 3.8 billion trees in urban areas (Dwyer, Nowak, \& Noble, 2003).

Trees can strongly influence the physical/biological environment by moderating climate, conserving energy, carbon dioxide, and water, improving air quality, controlling rainfall runoff and flooding, and lowering noise levels (Dwyer et al., 1992). Trees also play a strong role in the aesthetic landscape. Trees, shrubs, and a variety of plants are valuable community assets that enhance neighborhood beauty, recreation opportunities and wildlife habitat, and provide residents with opportunities to experience and understand forest-related benefits (Kuo \& Sullivan, 2001).

The importance of linking forestry and tourism has long been recognized and studied in forest management, community development and tourism. However, little has been written specifically about urban forests' role in sustainable urban tourism development. Urban forestry, blended with sustainable tourism, suggests that innovative ways of managing resources are needed and approaches that extend beyond traditional boundaries, such as involving a wide range of disciplines and stakeholders, in order to recognize the multiple values provided by each party involved (Konijinendijk et al., 2004).

\section{Purpose of Study}

The purpose of this study is to identify a range of stakeholder (tourism providers, resource managers, elected officials, tour operators and tourists) perceptions, issues and concerns of Savannah, Georgia's, urban forests to help develop opportunities for the growing sustainable tourism industry. Based on the three dimensions and the scope of sustainable development (description of scope discussed further in literature review), themes, trends and patterns that emerged were utilized to assess the current issues facing Savannah’s urban forest. 
This paper presents findings of a case study on sustainable urban tourism focusing on Savannah. Selected findings from stakeholder interviews are presented to help address the following research questions.

\section{Research Questions}

1. What are the positive and negative contributions of urban forests?

2. What role do urban forests play in tourism?

3. What does sustainable tourism mean in Savannah?

4. What are the economic impacts of developing and maintaining an urban forest? What are the environmental and social impacts?

5. What role does forest aesthetics play in urban tourism development?

\section{Limitations}

The majority of interview sessions were conducted in Savannah, GA. However, there were a few key stakeholders identified who were not located in the Savannah region. The questionnaire was sent and filled out via email.

Also, it would have been helpful to get a visitor's perspective on the subject, but unfortunately it was not possible. 


\section{Chapter 2. LITERATURE REVIEW}

In order to provide a foundation for the research questions identified in the previous section, a review of the literature on urban forests, urban tourism, sustainable development, and aesthetics is presented in this section.

\section{Urban Forests}

Urban forests are not only the trees and vegetation within a populated and developed area; they also consist of greenways, parks, squares, public spaces, residential areas, and watersheds. The first National Urban Forestry Conference was organized by the U.S. Forest Service in 1978 (Elmendorf, Cotrone, \& Mullen, 2003). Since then, numerous advancements in the field of urban forestry have taken place. Originally, urban forest management focused on managing and maintaining street and park trees; however, today, urban forestry also considers land use decisions related to natural resources and the preservation and management of trees and green space affected by development on private property (Elmendorf et al., 2003). City governments have enhanced their influence over urban forests because they could see the initial benefits the forests provided and also because they were able to create attractive environments for residents and businesses (Konijnendijk, 2008).

There are several benefits and costs to developing an urban forest. The most significant outcome is to maintain a maximum level of net environmental, ecological, social, and economic benefits over time (Clark et al., 1997). According to Dwyer et al. (1992), “urban forests can be seen as a living technology; a key component of the urban infrastructure that helps maintain a healthy environment for urban dwellers” (p.228). People tend to favor outdoor recreation areas close to home or within a reasonable walking distance; therefore urban green spaces are one of the most popular recreation areas (Konijnendijk, Sadio, Randrup, \& Schipperijn, 2004). 
The most valuable piece of the urban forest is the tree. With an average tree cover of 33.4 percent nationally, urban areas collectively support nearly one quarter of the nation's total tree canopy cover—some 74.4 billion trees (Dwyer et al., 2000). The environmental and ecological aspects of the urban forest are influenced by trees. Trees improve our air and water quality, conserve energy and carbon dioxide, and control storm water runoff and flooding.

Healthy trees act as air filters, contributing to an overall healthier air quality within the city. Tree foliage reduces particulate matter from the air, including dust, micro sized metals, and pollutants such as ozone, nitrogen oxides, ammonia and sulfur dioxides (Alliance for Community Trees, ACT, 2008). Filtration, when combined with the intake of carbon dioxide and the production of oxygen and the natural cooling effects, can have a significant effect on smog and reduce overall air pollution (SAF, 2007). Every 40 trees remove 80lbs. of air pollutants annually (ACT, 2008). Planting 500,000 trees in Tucson, AZ, was projected to reduce particulates by 6500 tons per year (Dwyer et al., 1992).

Trees also act as a filter for our water supply. Tree canopies and root systems reduce the volume of storm water runoff, flooding, and erosion. Computer simulations of deciduous trees in California's Central Valley estimate that for every 1000 trees, storm water runoff is reduced nearly 1 million gallons, a value of almost \$7000 (Center for Urban Research (CUFR), 2008).

A balanced ecosystem encourages a healthy environment. Urban forests promote ecological stability by providing habitat for wildlife, conserving soil and enhancing biodiversity (Dwyer et al., 1992). Developing and maintaining the green spaces within an urban area encourages environmental awareness and protection among residents and visitors.

Reduction of energy costs and carbon dioxide conservation can be attributed to trees. Trees decrease the cost of cooling and heating a home or building. Trees cool the air naturally 
from the effects of water evaporating from the leaves and from direct shade. Homes shaded by trees need less energy for cooling, 4 to 25 percent less, which means lower monthly utility bills (ACT, 2008; SAF, 2007). Winter wind protection can produce savings of as much as 10.3 thousand BTUs or approximately $\$ 52$ annually (Nowak et al., 1994). Four trees planted around each home could save up to 30 percent on summer cooling costs (ACT, 2008). Shade from two 25 -foot tall trees on the west and one on the east saves $\$ 57$ a year, or 23\%. Reduced energy use results in lower utility bills, less consumption of non-renewable resources, and fewer emissions released into the atmosphere (CUFR, 2008).

Trees also reduce the amount of carbon dioxide produced. Urban forests improve air quality by reducing atmospheric carbon dioxide levels and absorbing air pollutants. Trees can directly sequester carbon dioxide as woody and foliar biomass while they grow (CUFR, 2008). A study of one Southwest region's six million trees revealed that the trees removed and stored approximately 304,000 tons of atmospheric CO2, 12,000 tons of ozone, and 9,000 tons of particulates (CUFR, 2008).

The sociological and psychological dimensions of the urban forest present additional benefits to residents and visitors. The presence of trees, parks, and green spaces make urban areas a more enjoyable place to live, work, and play. Reduced stress and improved physical health have been associated with the presence of urban trees and forests (Dwyer et al., 1992). Surrounded by the built environment, green spaces give people the chance to recreate and relax. The urban forest acts as a catalyst for mental and physical well being, as well as fostering a sense of community (Konijnendijk, 2008).

Urban forests also contribute economic benefits to the metropolitan area. A few economic benefits include the increase in residential property value and the increase in local 
business. Shaded neighborhoods and well landscaped yards have a positive influence on real estate values, timeliness of house sales and neighborhood desirability (ACT, 2008). One tree in the front yard equals a 1 percent increase in the sale price of a home (CUFR, 2008).

Trees are also good for business. Consumers respond positively to shopping environments with healthy urban forests (ACT, 2008). With the presence of trees, business districts can enhance moods and attract more consumers. Shopping centers frequently landscape their surroundings in an effort to provide a pleasing environment; therefore increasing the value (Dwyer et al., 1992).

Although there are many benefits attributed to trees in the urban forest, if not managed and planned properly, there can be a considerable amount of costs. One of the most important costs is the annual maintenance per tree. Maintenance becomes important when considering utility line clearance, storm damage repair, debris removal, and protection from various pathogens (SAF, 2002). Education regarding the planting and care of appropriate tree species in desirable locations is critical to cost-effectiveness (Dwyer et al., 1992).

Another cost is the security risks involved in tree space and coverage. The placement of trees may increase apprehensive feelings of personal safety and security. In designing parks and other public spaces, public safety should be a key factor in placement, selection, and management of trees (Clark et al., 1997).

If properly managed and maintained, the trees of the urban forest will only benefit the local residents and visitors. Long-term planning, appropriate tree species selection, care and management practices, and establishing local budgets allows municipalities and communities to avoid unhealthy forests and damage litigation, while supporting lower costs for urban forestry programs (SAF, 2002). Trees are considered infrastructure. In order to ensure the health, safety, 
and welfare of citizens, tree risk management planning must be considered one of the most important phases of planning an urban forest (Barker, 2009). According to Barker (2009) a few ways to avoid damage litigation includes: conducting routine tree monitoring, maintenance, and post storm inspections; developing an emergency storm response plan; setting up tree trimming and debris removing contracts; and establishing procedures and policies for trees located on private land.

\section{Urban Tourism}

Urban tourism is defined as travel to an inner city or metropolitan area (dictionary, n.d). There are a multitude of reasons visitors choose urban areas as a tourism destination. The attractiveness of tourism in an urban environment depends more on the variety the city has to offer and not based on one individual element (Munoz, 2004). Family or friends, business, arts and entertainment, sporting events, cultural sites and heritage locations are just a few motivations for individuals traveling to cities. Cities are characterized by high populations, thereby attracting high numbers of tourists (Hinch, 1996).

Traveling to cities has dramatically increased since the 1980s. Therefore, travel and trends are set to remain favorable for the urban tourism market, further reinforcing the potential for growth (Scottish Parliament for Information, SPIC, 2002). Urban areas are characterized by the plethora of activities made available to the public. One can get almost anything they want in a city. With increasing pressures at work and little or no free time, there is a growing search for antidotes to stress; furthermore, shopping, eating, drinking, and entertainment are the fundamental remedies for stress levels of the average tourist and these desires are most likely to be fulfilled within the city environment (SPIC, 2002). 
Again, there are a variety of motives to why urban areas have seen an increase in traffic, but one major factor may be urban renewal. The increased interest in urban development and regeneration breathes life back into cities and fosters the rehabilitation of the historic centers and promotes cultural diversity in the community (European Commission, 2000). Urban regeneration invites more visitors to the area which would allow for further development and an increase in visitor spending.

Residents and visitors of a metropolitan area put high demands on the quality of businesses and life in the region, which gives cities the incentive to invest in the attractiveness of the city (Paskaleva-Shapira, 2007). Urban development does this by offering visitors a unique and original experience and by trying to satisfy residents' rightful hopes for balanced economic and social development, while at the same time demonstrating environmental concern (European Commission, 2000).

Tourism can be an important part of the city's economy and can contribute to the leisure and welfare of the whole community (Galdini, 2007). However, an urban region is also a place where thousands, even millions, of people call home. For that reason, urban tourism is dealing with two distinct markets: the visitor and the resident (Murphy, 1992). Resident's can also be potential customers of tourism products. Now, urban tourism has become a strategy for building quality services and products, encouraging sustainable management practices in the community, attracting responsible tourists, and a way of developing destinations that combine a comparative supply able to meet the visitor's expectations with a positive contribution to the development of cities and the well being of their residents (Paskaleva-Shapira, 2007).

Finding a balance between appealing to visitors and satisfying residents is essential to the long term viability of a city. Although the residents of the community may not experience every 
impact, whether positive or negative, brought on by tourism, it is necessary for elected officials, the tourism industry, and the residents to work cooperatively and carefully to plan for its growth and development (Galdini, 2007).

According to Pearce (2001), there are key themes to be addressed when examining urban tourism characteristics: demand, supply, development, marketing, planning, organization, operations, and impact assessment (p. 929). Although all of the above are important for the success of urban tourism development, marketing is one of the most important attributes to sustaining a city’s tourism future.

As tourism is an industry developing through competition for tourists, cities have to respond to the demand for comfort, reliability and quality in their tourism experience and at the same time advertise their abilities effectively (Asprogerakas, 2007). There are only so many options when choosing an urban region for a vacation. As a result, marketing has become the key component in the survival and development of tourism plans that are attempting to broaden their appeal and advertise to both residents and visitors (Murphy, 1992; Pearce, 2001, \& Bramwell, 1998).

Views on a tourism product in a city may vary between business tourists and leisure tourists, between family tourists and friend tourists, between day trippers and overnight visitors, and between visitors of different ages and nationalities (Bramwell, 1998). Tourism perceptions differ among individuals and we all have our own reasons for why we pick a destination. In tourism, it is the consumer, not the product, that moves and because the product is usually sold before the consumer sees it, the marketing of tourism is essentially more significant (Munoz, 2004). All cities have different assets that appeal to different publics. Marketing and 
interpretation assist in capitalizing on these assets and/or restorations that have taken in a city (Murphy, 1992).

Urban destinations need to develop their multifunctional products based on a strategic vision and also on a full understanding of the benefits sought by different users (Bramwell, 1998). If urban tourism wants to continue to grow and prosper, everyone, from the server in the restaurant to the gift shop owner should act as a tourism agent in order to provide the visitor with positive experiences (Ruetsche, 2006).

\section{Sustainable Development}

Sustainable development has been a profound topic of discussion among academia and professionals for the past 20 to 30 years. However, the issue has been around for centuries. Some of the earliest attempts to achieve sustainable development were the towns and cities which were planned and developed by the Romans (Swarbrooke, 1999).

Today, the rise of sustainable development popularity is due to the major changes in our global environment and the concerns for our environmental, socio-cultural and economic future. Whether they are called "green communities," "green cities”, or “ecocities,” sustainable places seek to limit environmental impacts and consumption of natural resources (Beatley \& Manning, 1997). Yet sustainability still remains elusive in finding a universal definition.

What is a sustainable place and how do we know what a sustainable place looks like? Beatley \& Manning (1997) explore many principles in an attempt to answer these questions and describe what sustainability can mean to a community. According to Beatley and Manning (1997), Sustainable places:

- Acknowledge Fundamental Ecological Limits- consider ecological limits and environmental impacts at every step of community development and design while 
reorganizing the social, physical, and political-economic landscape in fundamental ways.

- Are Restorative and Regenerative-focus efforts to reverse the current degradation in both the natural and built environment.

- Strive for a High Quality of Life-creating and supporting social and human sustainability through humane living environments, livable places, and communities.

- Place Matters- communities must take care of the built and natural environments to inspire a feeling of attachment and belonging.

- Are Integrative and Holistic-look beyond conventional solutions to social and environmental problems and address them from a broad viewpoint.

- Imply New Ethical Posture-implement ethical frameworks in which physical and social forms, consumption of land and resources, and basic operating principles are designed for the future.

- Strive to Be Equitable and Just-open to all racial, cultural, age and income groups and encourages social and cultural diversity.

- Stress the Importance of Community-alternative forms of politics concerned with issues that affect quality of life and involves all or most community groups.

- Reflect and Promote a Full-Cost Accounting of the Social and Environmental Costs of Public and Private Decisions-assess and understand the costs and plan accordingly.

As mentioned earlier, there is no precise way of defining and measuring sustainability. The above standards can act as guidelines when planning, developing, and maintaining a 
sustainable community. The basis of sustainable development (shown earlier in Figure 1) interconnects the social, environmental, and economic aspects and supports the foundation of these principles. Sustainable principles suggest a large improvement in our current way of thinking about communities through the union of social, economic and environmental behaviors (Beatley \& Manning, 1997).

Do to the increase in travel in the past years, sustainable tourism development has been a subject matter addressed by planners and mangers around the globe. Since tourism is one of the world's largest industries, it is widely accepted that tourism development may have a profound impact on the local environments, and that sustainable development of tourism destination areas is an important issue (Hunter, 2002). Sustainable tourism seeks to achieve the best balance between economic benefits and social and environmental costs (McKercher, 2003).

There are many different types of tourism and sustainable tourism encompasses many aspects of the general tourism industry (Figure 2). By embracing sustainable tourism development, both large and small scale tourism destinations can use their current knowledge and interpretations of sustainable development, combined with the ideas of others, to work towards the ultimate goal of sustainability (Clarke, 1997).

The scope of sustainable tourism helps to formulate an understanding of all the facets involved in achieving sustainability. The economic, environmental, and social dimensions are filed under a broad range of categories to emphasize that attaining the common goal of sustainable tourism is the responsibility of all, not solely the public officials and managers of a community. Sustainable tourism should rightly be the concern of every person (Swarbrooke, 1999). 


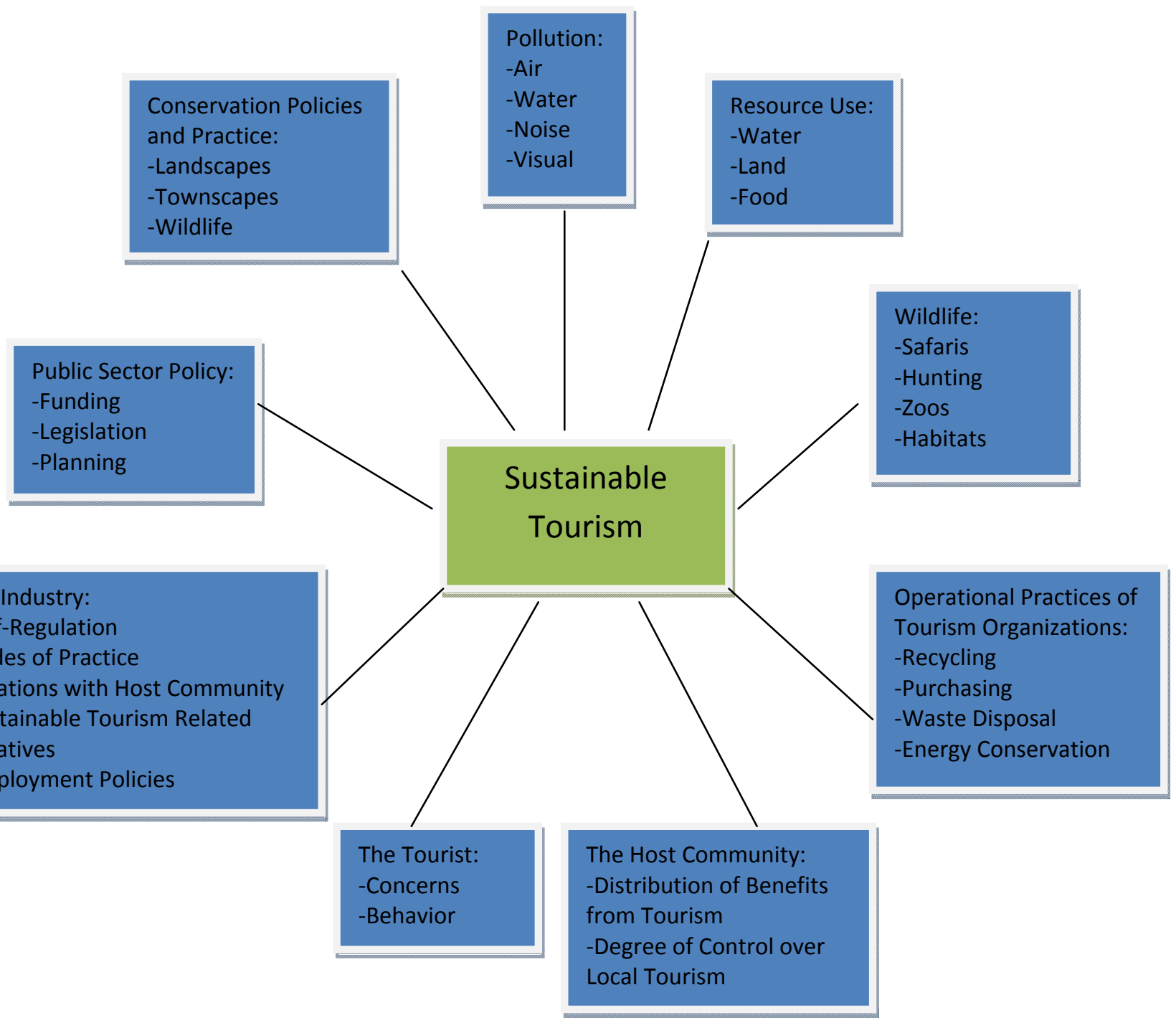

Figure 2. The Scope of Sustainable Tourism. Adapted from Swarbrooke (1999).

According to the WTO (2004), sustainable tourism development guidelines and management practices are applicable to all forms of tourism in all types of destinations, including mass tourism and the various niche tourism segments. Sustainability principles refer to the environmental, economic and socio-cultural aspects of tourism development, and a suitable balance must be established between these three dimensions to guarantee its long-term sustainability. Thus, sustainable tourism should: 
1) Make optimal use of environmental resources that constitute a key element in tourism development, maintaining essential ecological processes and helping to conserve natural heritage and biodiversity.

2) Respect the socio-cultural authenticity of host communities, conserve their built and living cultural heritage and traditional values, and contribute to inter-cultural understanding and tolerance.

3) Ensure viable, long-term economic operations, providing socio-economic benefits to all stakeholders that are fairly distributed, including stable employment and incomeearning opportunities and social services to host communities, and contributing to poverty alleviation.

4) Sustainable tourism development requires the informed participation of all relevant stakeholders, as well as strong political leadership to ensure wide participation and consensus building. Achieving sustainable tourism is a continuous process and it requires constant monitoring of impacts, introducing the necessary preventive and/or corrective measures whenever necessary.

5) Sustainable tourism should also maintain a high level of tourist satisfaction and ensure a meaningful experience to the tourists, raising their awareness about sustainability issues and promoting sustainable tourism practices amongst them.

The main concern for sustainable development in urban areas is the issue of managing the pressure of large tourism numbers in historic cities with fragile built environments (Swarbrooke, 1999). Considerable amounts of tourism in a central location can lead to traffic congestion, noise pollution and the possibility of a city losing its own sense of identity with the special places. According to Notarstefano (2007), the general concept of sustainable tourism 
development helps to set an agenda for more sustainable tourism that meets two elements: 1) the ability of tourism to continue as an activity in the future,; and 2) the ability of society and the environment to absorb and benefit from the impacts of tourism in a sustainable way (p.3).

Unlike traditional community development approaches, sustainability strategies emphasize: the whole community (instead of just disadvantaged neighborhoods); ecosystem protection; meaningful and broad-based citizen participation; and economic self-reliance (Institute for Sustainable Communities, 2008). Sustainable tourism is not a characteristic of any existing form or situation, but a goal that all tourism must strive to achieve (Clarke, 1997).

The scope of sustainable tourism in Figure 1 outlines the basic structure of a sustainable place. Notarstefano (2007) has taken this a step further and developed twelve aims to achieve the basic concepts of sustainable tourism:

\section{$\underline{\text { Aims }}$}

1) Economic Viability

2) Local prosperity

3) Employment Quality

4) Social Equity

\section{$\underline{\text { Actions }}$}

To ensure the viability and competitiveness of tourism destinations and enterprises, so that they are able to continue to prosper and deliver benefits in the long term.

To maximize the contribution of tourism to the economic prosperity of the host destination, including the proportion of visitor spending that is retained locally.

To strengthen the number and quality of local jobs created/supported by tourism, including the level of pay, conditions of service, availability to all without discrimination by gender, race, disability or other ways.

To seek a widespread and fair distribution of economic and social benefits from tourism throughout the recipient community, including improving opportunities, income and services available to the poor. 
5) Visitor Fulfillment

6) Local Control

7) Community Wellbeing

8) Cultural Richness

9) Physical Integrity

10) Biological Diversity

11) Resource Efficiency

12) Environmental Purity
To provide a safe, satisfying and fulfilling experience for visitors, available to all without discrimination by gender, race, disability or in other ways.

To engage and empower local communities in planning and decision making about the management and future development of tourism in their area, in consultation with other stakeholders

To maintain and strengthen the quality of life in local communities including social structures and access to resources, amenities, life support systems, avoiding any form of social degradation or exploitation.

To respect and enhance historic heritage, authentic culture, traditions, distinctiveness of host communities

To maintain and enhance the quality of landscapes, both urban and rural, and avoid the physical and visual degradation of the environment.

To support the conservation of natural areas, habitats, wildlife, and minimize damage to them.

To minimize the use of scarce and non-renewable resources in the development and operation of tourism facilities and services.

To minimize the pollution of air, water, land, the generation of waste by tourism enterprises and visitors (p.4).

The twelve aims mentioned above help support the previous sustainable tourism development model by Swarbrooke (1999) and the WTO (2004). However, it breaks the concepts down a bit further by expanding the resource needs and why they are important to a sustainable environment. This example provides additional reasons on why we need the twelve aims rather than only specifying who or what is involved.

Stakeholders involved in the tourism industry are the individuals who participate in the planning, development, implementation and enjoyment of sustainable tourism practices. The stakeholder's focus their attention on balancing the type and extent of the tourism activity against 
the capacity of the resources available; therefore, destinations are able to develop tourism policies that balance the needs of the industry, residents, and local community without compromising social, cultural and ecological integrity of the host environment (Timur, 2003). Tourists will recognize that places that care for the environment, their employees and the local communities will more likely care for the tourists and in return the visitor will care for the destination. (Notarstefano, 2007).

\section{Aesthetics}

Aesthetics is the study of the mind and emotions as it relates to our sense of beauty and refers to the perceptual way we experience the landscape (Lothian, 1999; Bell, 1999). The term aesthetics comes from the Classical Greek words aesthanesthai, to perceive, and aistheta, things perceived; therefore, perception is a way for us to understand our environment and is central to the scenic beauty and satisfaction we obtain from that environment (Bell, 1999). While other

senses influence our perception and experience of landscape, aesthetic perception occurs mainly through our sense of sight (Tyrvainen, Silvennoinen, \& Kolehmainen, 2003).

A landscape is an area of land that contains views and scenes and encompasses the ecological and geological processes contained in this particular area (Daniel, 2001). Landscape aesthetics based on preference and perception not only helped define how city parks were designed and how lands were preserved, but also how buildings were designed and urban areas were preserved (Gobster, 1999; Ewald, 2001). If design and preservation are key factors in landscape aesthetics, then there must also be an element of economics, ecology, and sociocultural aspects involved in planning and maintaining the landscape. This is especially true for urban areas considered tourism destinations. 
The landscape in an urban region is a resource made up of natural, physical, cultural, economic and visual elements (Bulcao, Ribeiro, Arsenio \& Abreu, 2004). A lot of times these components are considered separate entities throughout city planning processes. However, the economic, cultural and aesthetic values need to be linked together when developing conservation and management plans (Bulcao et al., 2004). Bourassa (1992) argues that landscape aesthetics has gone beyond personal interests in order to include public interests and management plans are being developed to monitor the aesthetic aspects of development. For example, he maintains that "the aesthetic value of the environment is a public good and aesthetic appreciation of one's surroundings generally does not reduce the amount of aesthetic quality available for others to appreciate” (p. 36).

There are two types of aesthetics that have been studied and argued throughout the years: ecological and scenic. Ecological aesthetics takes the biological principles of ecosystem management and treats the landscape as a feature to be classified and mapped (Parsons \& Daniel, 2002; Lothian, 1999). People with a greater knowledge of ecosystems, would more likely prefer ecologically sustainable landscapes (Gobster, 1999). On the other side of the debate is scenic aesthetics. Scenic aesthetics stems from the romantic ideals of paintings and literature and we view these landscapes passively, as if they were snapshots (Parsons \& Daniel, 2002).

According to Parsons \& Daniel (2002), scenic aesthetics are presumed to be inconsistent with ecological principles and sometimes considered to be inferior to the goals of environmental management. However, Gobster (1999) argues that scenic aesthetic management practices often focus on the visual designs of an ideal nature rather than one where the dynamics of change are apparent. He states that "by highlighting the picturesque attributes of nature; by treating the landscape as a static, formal composition; and by conceptualizing and measuring only the visual, 
perceptual, and affective aspects of human aesthetic response, we may be limiting the range and depth of aesthetic opportunities we afford our public (Gobster, 1999, p. 56).

Ecological aesthetics is on the other end of the spectrum from scenic aesthetics. It is more concerned with the sustainability of our ecosystems and not the visual beauty of the environment. The quality of the landscape is defined by three ecological characteristics: integrity, biodiversity, and sustainability (Parsons \& Daniel, 2002). According to Gobster (1999), in order to have ecological aesthetics, we must actively experience the landscape and realize it is a living landscape, not just merely watch it passively as if it were a picture. Gobster (1999) also advocates the fact that the idea of scenic aesthetics is deeply embedded in today's society, which makes it difficult for people to see the ecological beauty and accept practices that promote a more healthy, diverse, and sustainable forest even though it may look a little messier. Table 1 below illustrates the main differences in scenic versus ecological aesthetics. 
Table 1. Differences in Scenic and Ecological Aesthetics

\begin{tabular}{|c|c|}
\hline Scenic Aesthetics & Ecological Aesthetics \\
\hline Perceptual/immediate & Knowledge-based \\
\hline Stimulus-response & Experiential \\
\hline Affective/emotional & Cognitive/refined \\
\hline Visual/static/inanimate & Multi-model/dynamic/animate \\
\hline Picturesque/composed & Vernacular/symbolic \\
\hline Naturalistic/dramatic & Natural/subtle/unscenic \\
\hline Passive/object-oriented & Active/participatory \\
\hline Benefits/outcomes & Benefits/outcomes \\
\hline Pleasure & Understanding and pleasure \\
\hline Short-term mood change & $\begin{array}{l}\text { Long-lasting, restorative, deep } \\
\text { values, unity, sense of place }\end{array}$ \\
\hline Maintains status quo & $\begin{array}{l}\text { Catalyst for internal and external } \\
\text { change }\end{array}$ \\
\hline
\end{tabular}

Human aesthetic preferences should still be consistent with the principles of responsible ecosystem management (Parsons \& Daniel, 2002). As Gobster (1999) states, ecological aesthetics offer guidance for merging biological and ecological ideas of sustainability with aesthetic appreciation (Gobster, 1999).

In a study done by Pierskalla, Saunders, McGill and Smaldone (2007) to examine how education relates to perceptions of scenic beauty, students were split into four groups and administered four different educational programs (i.e., no pre-educational experience, lecture only, lecture/video, and lecture/video/walk-in-the-woods) that were related to forest settings. 
The researchers found that education, especially through demonstrations, can enhance perceptions of scenic beauty to include ecological processes and sustainable forest management practices that may otherwise be considered unsightly (Pierskalla et al., 2007). This study supports Tyrvainen and Lofstrum's (1998) and Gobster's (1999) idea that active participation may increase the participants' ecological knowledge, therefore changing their view and preferences toward forest management practices.

The aesthetic appreciation of nature involves the activation of systems of behavior, or at least the activation of cognitive mechanisms that help mediate behavioral systems (Averill, Stanat, \& More, 1998). For a person to appreciate nature or a particular place, they usually have developed a special connection with that place. Parsons and Daniel (2002) maintain that forming an emotional attachment to a site by experience will trigger a greater appreciation for sustainable management as well as cognitive approaches to understanding and adopting conservation ethics. Our direct relationship with a location will forecast our behavioral intentions. When we consider landscape in the sense of scenery, our visual impression is the most important for perception and the aesthetic response (Bell, 1999).

An urban forest encompasses both aspects of aesthetics. Urban forests are made up of trees, shrubbery, parks, and squares. In order to effectively design an urban forest, planners must examine and evaluate the ecosystem and develop an efficient pattern that does not compromise the current state of the environment. In order to move toward a sustainable urban forest, preferences for maintaining and restoring the ecological structure and function of ecosystems and for preserving and enhancing the health and diversity of native species and ecological communities must come first (Gobster, 1999). Managers, planners and developers may use 
Geographic Information Systems (GIS) mapping as one of the tools to assess the area and protect the forests.

Scenic aesthetics is also an important characteristic of urban forestry design. The cliché "beauty is in the eye of the beholder" can be related to scenic aesthetics. Landscape is taken to be beautiful, but in actuality this beauty is literally a figment of the imagination, a product of the viewer's own cultural, social and psychological constitution (Lothian, 1999). Urban forestry managers and planners want to propose a blueprint that is not only environmentally sustainable, but attractive as well. The beauty of an open green space, park, or square allows individuals the opportunity to participate in recreational activities, relaxation and encourage feelings of place attachment (Averill, Stanat, \& More, 1998). In order to protect, manage or create landscapes that enrich our lives, we need to acknowledge that enrichment occurs to a large degree by providing aesthetic pleasure (Bell, 1999). The combination of both will lead to the development of a sustainable urban forest and community. 


\section{Chapter 3. METHODOLOGY}

To address the research questions in this study, stakeholders in the fields of tourism, urban forestry, and resource management, as well as elected officials, were interviewed to identify the perceptions, issues and concerns of urban forests as they relate to the growing sustainable tourism industry. A discussion of the study area is presented in this section.

\section{Savannah, Georgia}

Savannah, Georgia, is situated on a 40 foot bluff overlooking the Savannah River, eighteen miles from the Atlantic Ocean. The city was founded in 1773 by General James Edward Oglethorpe, a member of the English Parliament. Oglethorpe named the 13th and last colonial capital to be established by the British in America "Georgia" after England's King George II and Savannah became the first city (New Georgia Encyclopedia, 2008).

Known as “America’s first planned city”, Savannah was designed around 24 squares placed at regular intervals (Figure 3.). Oglethorpe laid the city out in a series of grids that allowed for wide open streets intertwined with shady public squares and parks that served as town meeting places and centers of business (Savannah Area Convention and Visitor's Bureau (CVB), 2008). Today there are still 21 squares still in existence and number 22, Ellis Square, is in the process of reconstruction. Because of its long standing commitment to urban forest management, Savannah has been recognized by the National Arbor Day Foundation as a Tree City USA since 1983. 


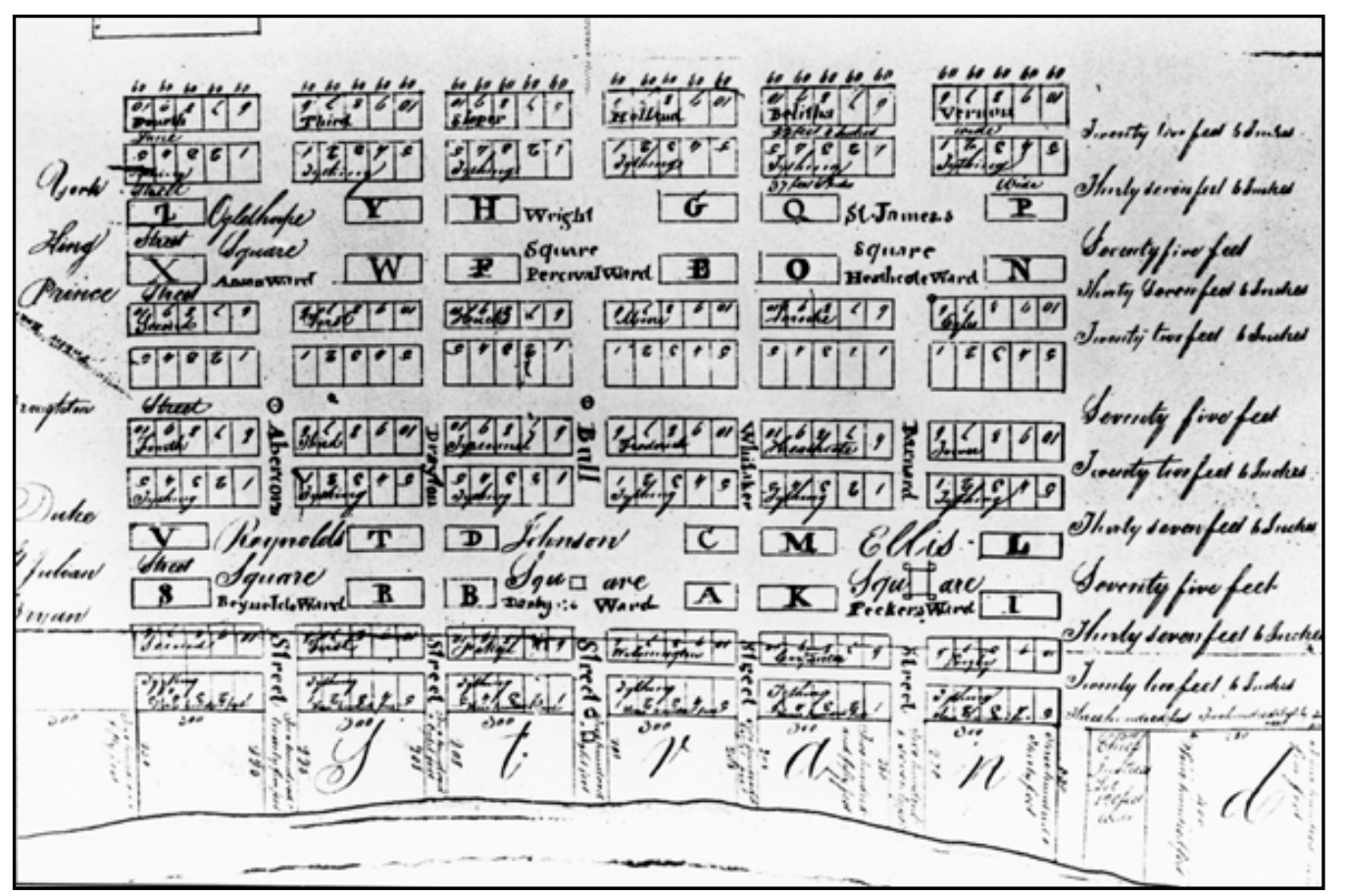

Figure 3. Savannah City Plan 1770. Courtesy of Hargrett Rare Book and Manuscript Library, University of Georgia Libraries

In the beginning, Savannah's early fortune was built on the rich soil favorable for the cultivation of cotton, rice, and tobacco. In 1793, Eli Whitney developed the cotton gin on a plantation outside of Savannah, which led to the Savannah becoming a prosperous commercial port (CVB, 2008). By the early 1870s Savannah had achieved commercial prosperity through its export of cotton. From the 1880s until the 1920s, Savannah was the world's leading exporter of naval stores products. By 1905 Savannah's exports, chiefly cotton and naval stores, were greater than the combined exports of all other south Atlantic seaports. In the $20^{\text {th }}$ century, Savannah's port facilities played a prominent role in World War II. It was one of the nation's most active Atlantic shipyards for the construction of Liberty Ship transports for the U.S. war effort (NGE, 2008). Today, port activity is the largest industry in Savannah.

Although the city of Savannah prospered, it also suffered many misfortunes over the years, i.e. devastating fires, the yellow fever epidemic, hurricanes and war; however, it always 
managed to rise from the ashes. During the $20^{\text {th }}$ century, Savannah's old town charm was beginning to fade. Resident's were moving to the suburbs, Savannah abandoned the grid layout, and the old buildings began to deteriorate (Essential Guide to Savannah, 2008). In the 1950s, a group of women united and began preserving Savannah’s historic architecture and original attraction. They eventually formed the Historic Savannah Foundation. Savannah's Historic District was designated a National Historic Landmark in 1966 and is one of the largest historic landmarks in the country (CVB, 2008). Today, Savannah is considered a model for historic preservation.

In the 1990s, more than 50 million people came to visit Savannah, attracted by history, culture and natural beauty. Savannah's historic district and riverfront are complete with restaurants, bars, and storefronts. Architecture, fountains, and the green squares add to the charm of this notable city. The history and the urban forests have made Savannah one of the country's most popular vacation spots. The large, restored historic district, moss draped oaks, and Southern hospitality are drawing tourists from all over this country and many others (Essential Guide to Savannah, 1998). As shown in Figure 4, Savannah’s squares offer residents and visitors a unique urban forest in the middle of a concrete jungle. 


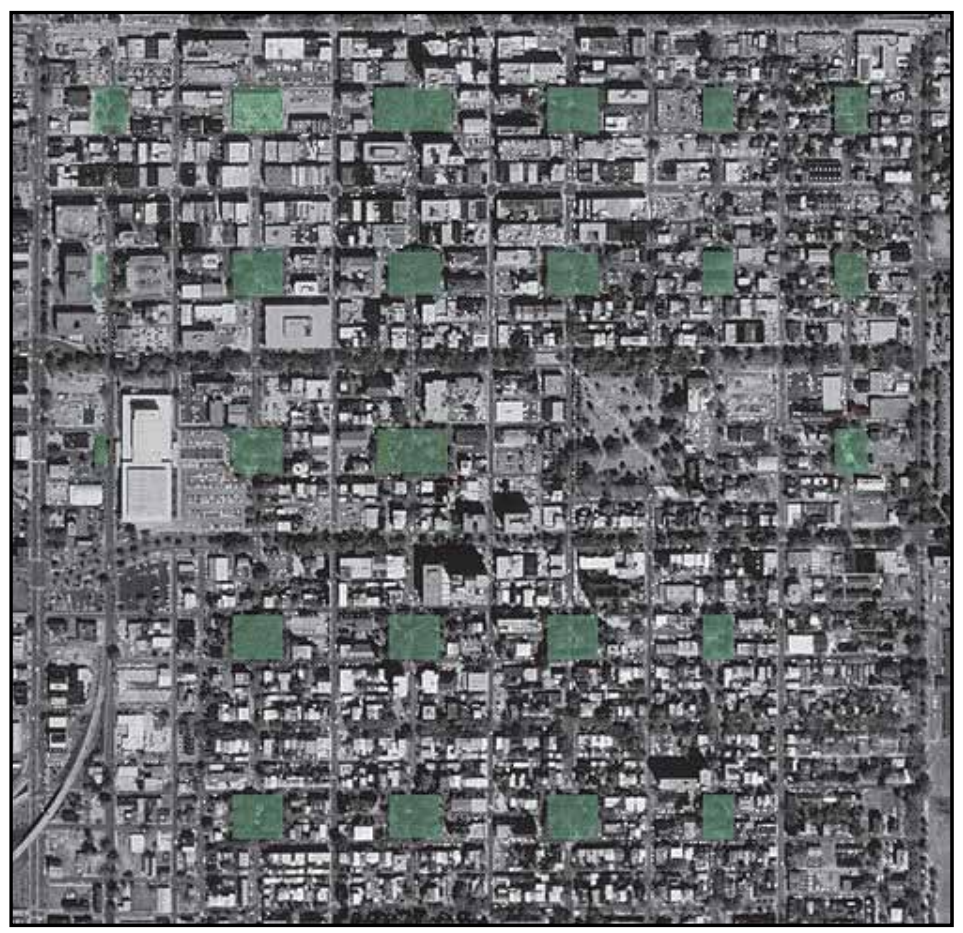

Figure 4. Aerial photography of present day Savannah, courtesy of Wikipedia, 2009.

\section{Sustainable Savannah}

Savannah is making strides in becoming a sustainable city. In August 2008, at a Town Hall Meeting, Savannah introduced its new sustainability plan, Thrive (Citizens’ Report, 2009). The goal of Thrive is to consolidate all of Savannah's sustainable initiatives and integrate new programs in an effort to reduce the city's carbon footprint by 15 percent over the next decade (Citizens’ Report, 2009).

Savannah has also developed an affiliation with the Partnership for a Sustainable Georgia, which is a state sponsored voluntary environmental leadership initiative run by the Georgia Department of Natural Resources (Citizens’ Report, 2009). Collaborating with Partnership for a Sustainable Georgia has provided Savannah with an opportunity to access statefunded training and technical assistance in the areas of pollution prevention, resource conservation, waste reduction, by-product re-use and recycling (Citizens’ Report, 2009). A few 
examples of some of the current programs include: Operation Clean Sweep, the Earth Day Festival, and Dump the Pump. Savannah has also converted over a dozen work trucks to run on biodiesel fuel, converted all traffic lights to LED’s, implemented curbside recycling and increased tree plantings (Citizens’ Report, 2009).

Although not directly related to the tourism industry, Thrive initiated programs are part of the overall sustainable development ideals in Savannah and tourism is an important commodity in Savannah. Tourism is the number two economic generator in Savannah (Personal Communication, January 8, 2009). The outcomes of Thrive initiatives and other sustainable programs in Savannah will affect both residents and visitors alike. However, the Thrive committee is only one of many organization's transforming Savannah into a green city. I believe the main goal for all is to educate visitors and residents on sustainable development and continually update them on the progress, which in turn will most likely ensure quality outcomes.

\section{Methods}

To address the objectives in this study, findings from a qualitative interview session were used to help answer several research questions and research implications will be discussed.

Stakeholder interviews were conducted in January, 2009 and August, 2009.

\section{Stakeholder Interviews}

Stakeholder interviews were conducted using a semi-structured, open-ended questionnaire (see Appendix A). By conducting qualitative interviews, important aspects about the participant's perspective and experiences emerge that may have not been realized in a quantitative survey (Kiernan, Kiernan, \& Goldberg, 2003).

Savannah is a large city and several people are involved in the urban forestry and tourism industry. The stakeholders for this study were identified based on their relationship with 
planning, maintaining and managing the urban forests and tourism industry in Savannah.

Fourteen stakeholders were invited to participate in an interview session using an open ended, semi-structured questionnaire and a total of 12 individuals participated in separate interview sessions. Individuals from 10 different businesses, agencies, offices and organizations that represent Savannah's urban forest and tourism industry agreed to contribute to this study. Three interviews were conducted in January, 2009 and seven interviews were completed in August, 2009. Two questionnaires were sent, completed and returned via email due to the fact that the offices were not located in the Savannah region. The semi-structured interview sessions lasted between 30 minutes to one hour.

\section{Study Instrument}

The study instrument used in this thesis was a semi-structured interview questionnaire and consisted of nine questions (see Appendix B). The design of the interview questionnaire was developed based on the key components related to urban forestry, sustainability and tourism in Savannah. The interview started with an introduction of the study and the participants were asked if he or she would mind being recorded for accuracy. All respondents participating in the interview sessions agreed to be recorded and the names of all participants, both interview and email, will remain anonymous. Next, the interviewee asked the participants to state their job title and give a little bit of background information on the function of the department, office, agency or organization. In the first question, the interviewee asked the participants to identify the most important issues facing Savannah's tourism industry today. The next question asked participants to define sustainability and the role it plays in tourism development and how he or she views urban forestry as a contributor to sustainable communities. In the next interview question, the respondents were asked to identify the positive and negative contributions of urban forests in 
Savannah. Subsequently, the respondents were asked to identify the economic impacts of developing and maintaining an urban forest, as well the environmental and social impacts. The next question asked what role do trees play in attracting visitor's to Savannah. Following that question, participants were asked what objectives are considered the most viable to implementing and managing a successful outcome. The next two questions asked the participants to identify the wishes, dreams, and hopes for the future of Savannah's tourism industry and then the fears and concern's for Savannah's tourism future. Finally, the respondents were asked to identify a special place that captures the essence of Savannah.

\section{Data Analysis}

Qualitative research methods were used in this study because qualitative research uses words, images, impressions, gestures, or tones which represent real events (O’Connor, n.d.). Qualitative research "generates theories that emerge from observations and interviews in the real world rather than in a laboratory or academy" (Patton, 2002, p. 11). In contrast to quantitative research, qualitative research gives the researcher a variety of options when exploring a subject, such as open ended interviews, observations, and written documents (Patton, 2002). For the purpose of this study, the information obtained was based on the interviews conducted with the previously mentioned stakeholders, as well as brochures, newsletters and reports on urban forestry and sustainability in Savannah.

To address the research questions in this study, the data was analyzed using content analysis to identify the range of values, meanings and desired conditions working toward a sustainable future. Content analysis is a data reduction technique and is useful for examining trends and patterns in documents (Stemler, 2001). Throughout data analysis the interviews were scanned for commonalities and differences. Once the similarities and differences were 
identified, the data was then separated into different categories. Content analysis is also effective for sorting the content into themes and developing a coding system to reorganize the wealth of data (O’Connor, n.d.). After the data was separated into different categories, a network of themes and subthemes were developed based on the trends, patterns and main ideas that emerged based on the overlapping principles of sustainable development. The themes were then used to examine and compare the relationship to the three dimensions of sustainable development (economical, environmental, and social) and the scope of sustainable tourism. 


\section{Chapter 4. RESULTS}

The interview questionnaire was developed to determine the issues and concerns of stakeholders in Savannah, Georgia's urban forestry and tourism industry. The goal of this research is to identify a range of stakeholder perceptions in order to develop a network of themes, trends and patterns to assess the role of urban forests in sustainable tourism development.

\section{Theme Development}

Through careful data analysis, there were several themes and patterns that emerged. I was able to reduce the vast amount of themes, trends, and patterns into four overall themes that represent stakeholder's views and perceptions of urban forestry as it contributes to sustainable tourism development. Some of the original themes developed fell into multiple categories. The themes are illustrated in Table 2.

Table 2. Four main themes and trends in Savannah's Urban Forest

\begin{tabular}{|c|c|}
\hline \begin{tabular}{ll} 
& \multicolumn{1}{c}{ Development } \\
- & Tree Points \\
- & Zoning \\
- & Ordinances \\
- & Overrun \\
- & Heat Island Effect \\
- & Advertising \\
- & Competition \\
- & Parking \\
- & Recession
\end{tabular} & \begin{tabular}{ll} 
& \multicolumn{1}{c}{ Preservation } \\
- & Protection \\
- & Maintenance \\
- & Maintaining \\
- & Zoning \\
- & Ordinances \\
- & Upgrading \\
- & Aesthetics
\end{tabular} \\
\hline $\begin{array}{ll} & \text { Balance } \\
\text { - } & \text { Appreciation } \\
\text { - } & \text { Quality of life } \\
\text { - } & \text { Safety } \\
\text { - } & \text { Ordinances } \\
\text { - } & \text { Parking }\end{array}$ & \begin{tabular}{ll} 
& \multicolumn{1}{c}{ Diversity } \\
- & Uniqueness \\
- & Walkability \\
- & Gathering \\
- & Year-Round Destination
\end{tabular} \\
\hline
\end{tabular}


The first theme in building a connection between urban forestry and sustainable tourism that emerged was development. Development is a very broad term and carries many different meanings. In Savannah, development takes on multiple definitions, both positive and negative. Development in Savannah not only refers to new projects throughout the city, but also to restorations of existing structures. In Savannah, ordinances and laws have been established to ensure proper construction, along with restorations, adhere to rules that make certain there is continuity throughout the historic district. A few examples include tree points, parking issues, public transportation, and the heat island effect.

Development also refers to the tourism industry in Savannah. There could be high costs attributed to improving advertising campaigns to appeal to visitors, as well as the cost associated with keeping up with competing tourism destinations. An increase in tourism may also lead to an increase in development. If not careful, there is a chance of the city being overrun by tourism development.

The second theme that surfaced was preservation. In order for urban forestry and tourism to continue to prosper, proper management and maintenance of both are vital to the future of Savannah. The key to preservation is to protect the urban forests of Savannah through continual maintenance. This includes appropriate tree selection for planting, removing trees when they start decaying, timely clean-ups after storms, and regular conservation issues. Savannah had developed specific laws and ordinances to safeguard the urban forests for the future.

The third theme that materialized was balance. Although tourism is the number two industry in Savannah, it is essential to evaluate the needs of the residents versus the wants of the visitors. Savannah is a working city and many residents live around the 21 squares. For 
Savannah to maintain a healthy urban environment, a central balance between both parties must be established. A healthy balance leads to an increase in the quality of life for both residents and visitors, encourages appreciation for the immediate surroundings and promotes a safe environment. Noise ordinances have been created to help mitigate the noise levels around residential squares. Public transportation has also been made available to alleviate some of the parking issues in the historic district.

The fourth theme to transpire was diversity. Diversity consists of all the distinctive aspects the makeup Savannah. Savannah is unique in the sense that it has a diverse set of assets and it is a year round destination. It is not only an urban forest, but it is a city also steeped in history. Some visitors come to Savannah for the architecture, some for the art. Since it is a coastal community, many pass through on the way to the beach. In addition, the military has a large presence in Savannah, as well as the art school SCAD, which appeals to art students around the world.

The squares and parks throughout Savannah are not only aesthetically pleasing, but they also promote social gatherings and long walks. It is not unusual to see weddings, picnics, lunches or business meetings happening in one of the squares or parks. The parks and squares also hold festivals, concerts, and farmer's markets. The combination of these varied resources in Savannah not only attracts visitors from all over the world, but continues to bring the tourists back, as well as attract new residents.

All four of the main themes that emerged are supported in the following sections: positive contributions, negative contributions, economic impacts, environmental impacts, and social impacts. 


\section{Positive Contributions}

The positive contributions are related to urban forestry and tourism development. There are many positive contributions of the urban forest as it is associated with tourism. One statement made by a participant is crucial in assessing the positive contributions of the urban forest, "The rules that preserve the urban forest preserve the land." The importance of preserving and maintaining the urban forests will help protect the other resources in Savannah, which leads to positive feedback.

Five out of 12 stakeholders agree that aesthetic appeal is a significant factor in identifying positive contributions. For example, one noted, "The aesthetic contributions are very positive and can in part be attributed to the city’s tourism industry.” Another participant states, “The positive would first of all be the visual effect of driving down the streets and it creates a better environment for pedestrians.”

An additional positive contribution reinforced by the participants was the walkability of Savannah. Eight out of 12 stakeholders express the importance of exploring Savannah on foot. One participant addresses this contribution by stating, "What makes this city so popular and so attractive is that everything is in human scale. This is very much a walking city.”

From walking tours to walking at your own pace, Savannah’s urban forests allow visitors to comfortably walk through the town and squares by cooling the air, “especially in July and August.” Another stakeholder recognizes the sustainable intentions for walking. "We encourage people to visit Savannah on foot which would help reduce our carbon footprint.” One participant summed it up best, "the whole time you were in the trolley, Savannah was begging you to get out and walk.” 
Another main positive contribution is the trees themselves. Twelve out of 12 stakeholders agree that the trees are a dynamic portion of Savannah's culture. However, only 5 out of twelve mention the environmental benefits. As one stakeholder puts it, "The trees are the show.” Another participant confirms this statement, "What trees provide can never be replaced.” Further information on trees will be discussed in the following pages.

Although less than half of the stakeholders specifically mention the environmental benefits during the positive contribution question, all 12 mention the benefits throughout the interviews.

\section{Negative Contributions}

Negative contributions are also a part of maintaining an urban forest and the tourism industry. Eight out of twelve reference the maintenance costs and liability issues of the urban forest. A few of the negative contributions include the removal of storm debris; the cost of maintenance and the upkeep of the trees; liability issues, such as falling limbs and falling trees; tree roots, such as uprooting sidewalks and damaging driveways; and vandalism, the breaking off of limbs by people or busses. Yet one participant explained, "We've got a great resource that provides huge benefits. If you can perceive it as a negative, it would be the cost associated with maintaining the resources we have.”

An additional negative contribution was attributed to development. Three out of 12 identify development as a negative contribution. The urban forest makes development more difficult. As one stakeholder remarked, “developers want to maximize the space that they can by clear cutting areas.” However, in order to maintain the integrity of Savannah's historic district, developers must follow strict zoning laws and ordinances. For instance, one participant stated, “all commercial development must have a certain number of tree points and landscape points in 
their site plan”. Depending on what you are building and the size of the building, you have to have so many points. A point system was designed for large, medium, and small trees, as well as "pruny or woody type shrubs". This system is not only required for the historic district, but residents and businesses in the sub-divisions must also adhere to the same laws and ordinances. As one noted, “If you don't have the tree points, you have to pay into a fund and that fund helps to plant trees in other areas.”

\section{Economic Impacts}

In light of the recent economic recession, Savannah is a city that has seen a reduction in tourism profits, yet because it relies on other industries for stability, the city has not seen a complete economic downturn. One participant explained, "We have the port, we have tourism, we have students from SCAD [Savannah College of Art and Design], we have the military, so we've got a diverse set of different types of economic generators that help to balance us out as we go through transition." However, another argued that "maintaining what we have is critical to the future of this town because tourism is one of the four primary economic drivers of this community." Six out of 12 talk about the maintenance/ preservation of the urban forest as having a key economic impact. As a result, Savannah is able to balance the state of the economy, but recognize that tourism is the number two industry and sustaining tourism is necessary.

In regards to balance, Savannah does have economic stability due to the multiple industries in the region, but the city must again be able to balance the conflict between residents and visitors, as well as the influx of new businesses and development in the area, which could have an impact on the tourism industry. Five out of 12 stakeholders acknowledged development as an economic impact. One stakeholder said, "We recognize the economic benefit of having the 
tourism industry here, but I think the main thing is being able to balance the people who live here with the increase of people who are visiting here and occasionally we do have conflict in balancing issues and relationships with the neighborhood versus the tourism industry.” Another noted, "One of the challenges is how do you maintain that balance of the beauty and authenticity that brought you to the dance and that injection of new goods and services that is inevitable?”

A few other economic impacts include the taxes and fees that are collected to maintain the urban forest. A dollar from each water bill goes toward planting another live oak with the option to contribute more money on each bill; a dollar from each tour, i.e. walking tour, ghost tour, trolley tour, etc., is put into a preservation fee which goes to restoring the monuments in the squares, as well as other aspects in preserving the historic district; a dollar is charged for any person sleeping in a hotel in the downtown area and that revenue supports tourism infrastructure projects; and lastly, residents of Savannah voted to pass a tax to restore Ellis Square.

Another economic impact was the aesthetic environment of the trees in Savannah. As one stakeholder puts it, “an aesthetic environment such as Savannah’s stimulates commercial activity; people will linger longer and shop more.” Trees also increase the property value of homes by almost 20 percent and planting trees around the home can also reduce heating and cooling costs. One out of 12 stakeholders' mentions the property value increase associated with economic impacts and 1 out of 12 discuss the cooling costs.

An added economic impact is advertising. When it comes to tourism, Savannah competes with other cities, such as Charleston, SC, and Jacksonville, Fl, to attract visitors. The urban forest is a large commodity when attracting visitors to Savannah and the trees are the focal point. As one participant described, "The trees are the show and the impact of the trees on the visitor experience is huge, it's huge. So the trees are marketing tools.” Another participant 
agreed, "I think portraying the city as a romantic, as a treed city, the history that is within the city, I think that is what draws so many people here to begin with and I think the trees keep them coming back.

Two out of twelve stakeholders' mentioned that the urban forests of Savannah have not been quantified; therefore, they did not comment on the economic impacts of the forests on tourism. Only one stakeholder brought up jobs as a direct economic impact.

\section{Environmental Impacts}

The urban forest and tourism in Savannah also leads to several environmental impacts. Minimizing these impacts is vital to Savannah’s infrastructure. As one participant points out, “The way the city was developed from 1733 to the present allowed us to have an urban forest. Maintaining it is just what we do with the legacy.”

Twelve out of 12 participants agree that trees play a large role in minimizing the environmental impacts in Savannah. Four out of 12 participants agree that the trees reduce the heat island effect and they also reduce the amount of pollutants in the air. "Their beauty and their benefit to the environment, as far as providing shade, cleaning the air and the aesthetics of it all,” relates to the overall quality of the environment as one participant noted.

The main environmental concern for 6 out of 12 stakeholders' was the ability to maintain and preserve the urban forest while continuing to develop the tourism industry. For example on stated, “There is a strong influence on how development will affect the ecology and the human demographic of things.” One participant hoped that "we can grow with great care and planning and protect what we have.” Another participant anticipated "a movement toward an enhanced environment where the human network and natural systems are complimentary.” 
Savannah has a standard planting program and the city plants close to 1000 trees annually. For every tree that is removed, 100 percent of the chips are recycled for mulching. The city also plants trees appropriate to the area. As one points out, "we have keep in mind that we need trees that are storm resistant because we are a coastal community.”

\section{Social Impacts}

Social impacts are another significant feature when assessing tourism and urban forestry. Twelve out of 12 participants agreed that an urban forest enhances the quality of life and instills a sense of community amongst the residents. For instance, one stakeholder noted "the urban forest improves the quality of life for people who live here or visit here and you feel better in the presence of trees"

Trees also create a sense of community pride and the squares in Savannah act as a gathering spot for friends, families, residents and visitors. The community has recognized the asset of having the squares. Weddings, festivals, and art shows are a few examples of residents and visitors utilizing the squares as public congregation areas. According to one participant, "People who live in a well-maintained urban forest are prouder of their community and are outdoors more often, which contributes to more physical activity and better health.”

The urban forest also promotes physical health benefits, psychological tranquility, as well as protection from the sun's harmful rays. Four out of 12 describe the pedestrian comfort and calming connected with the urban forest. "Urban forestry is very important because it helps to create that pedestrian scale and comfortable environment,” stated one participant.

In relation to tourism, the trees attract people to Savannah. "If the trees weren't there, there would still be people interested in the architecture and everything but I think they provide 
sort of a setting for the whole city really," stated a participant. Another said, "Visitors entering a city that has a healthy urban forest have a more positive perception of that city.”

However, there were three negative social impacts that stakeholder's associated with tourism and the urban forest. Three out of 12 mentioned vandalism; 3 out of 12 discussed the disturbances caused by tourism; and 3 out of 12 were concerned about safety issues.

Stakeholder's concerned with vandalism talked about the damage done to trees, for instance branches broken off by people or busses; as well as graffiti on monuments, statues, etc. The disturbances mentioned were the concerns for the individuals who reside in the historic district. The residents who live around the squares are sometimes agitated by the tour groups traveling around the squares. For example, people who are screaming from the ghost tours or people taking pictures of a resident's home at midnight.

In order to somewhat mitigate the disruption, there is a provision in the local ordinance in which a specific area can be designated a hot spot. One participant confirmed that, "We can say no walking tours can go through here after 9 p.m. Monday through Saturday, Sunday at 6 o'clock it has to stop. The hot spots are primarily based on complaints, as well as the city doing extensive research, mystery shopping a tour to figure out if the concerns are legitimate. So tourism management is key.” The general safety concerns were attributed to visitors throughout the historic district. As one participant noted, “If something happens to you, you won't want to come back.”

\section{Visitation}

Savannah has only been a tourism destination for around "20 years". Travelers have been coming to Savannah from all over the world. However, since the economic slowdown, Savannah has seen a decrease in long distance travel and more local visitors. According to one 
stakeholder, “We're not getting as many tourist’s from distant places like we used to but fortunately, stay-cations have helped us draw in more regional tourist's, people from what we like to say a tank in a day drive”. A stay-cation is a new expression for visitors driving to a local destination rather than flying to a faraway place or driving for extended periods of time (Personal Communication, August, 3).

In terms of the visitors traveling to Savannah, the four states with the largest number of visitors are Georgia, Florida, North Carolina and South Carolina, “which makes sense because we're in Georgia, South Carolina is across the bridge and Florida is right over there.”

\section{Wishes, Hopes, \& Dreams}

The wishes, hopes, and dreams of any city are the ideal situations or outcomes one looks forward to and the goals the city hopes to attain. In Savannah, the stakeholders expressed many wishes, hopes, and dreams for the future of this historic city. However, there were two main overarching themes that emerged: healthy balance and economic rebound. Twelve out of 12 agreed.

The biggest hope was that Savannah can continue to balance tourism with the quality of life of the residents. Savannah is a living, breathing city with a population of close to 140,000 people (City Financials, 2008). Yet Savannah is also a large tourist destination, attracting approximately 6 million visitors in 2005 (CVB, 2008). As one stakeholder explained, "My hope is that tourism can be managed in a way that respects both the residential side of things, the residents, and the tourism industry and what we have a good balance.”

One stakeholder combined balance with the economy, "I think we need to work on getting a longer stay and continue to do a better job addressing the issues of tourist's vs. locals 
and how they blend together and interact together so it doesn't become a conflict, because it can.”

One of the ways tourism and residents conflict is through the trolley tours, walking tours, horse and buggy tours, ghost tours, etc. Throughout the day tours are constantly going around the squares and residents live around the squares. As one stakeholder noted, "It is sometimes unpleasant for residents to hear the same stories day in and day out.”

The other major wish is that Savannah bounces back quickly from the current state of the economy. As mentioned earlier, Savannah has seen a decline in tourism numbers. According to one stakeholder: "Savannah, its vitality as a community is linked to tourism and the economic impact of Savannah with tourism is huge." Another stakeholder hoped "that the economy quickly rebounds and that we keep on doing what we are doing.”

\section{Fears and Concerns}

In developing and maintaining an urban forest and tourism industry, fears and concerns for the future of a city are an important entity. Although there were also many fears and concerns, establishing the fears and concerns for the future of Savannah's urban forest and sustainable tourism led to two main themes: Development and Natural Disaster. Nine out of 12 are concerned with development and the recession and 6 out of 12 are concerned that a natural disaster could devastate Savannah.

In this case, development can be defined as too much development and properly managing the development. As one stakeholder put it, "I hope Savannah cannot be overly dependent on continuing to grow. If it either becomes too over developed or too expensive where people can't afford to live there anymore or SCAD students can’t afford to be downtown, it’s going to create sort of an artificial environment. It is still an authentic city with commerce 
and education and daily life going on, as well as tourists walking around, which I think is neat. Continuous growth, I think that can be harmful at some point.”

Another developmental fear is one that requires managing development and the volume of visitor traffic coming to Savannah. Again, tourism is the number two industry and being able to balance tourism and development is crucial. One stakeholder states, "making sure we don't have too many large scale hotels that are built; we don't have too many tour companies going around the squares; recognizing that tourism is a very important industry for Savannah, but just making sure that we have systems in place to help manage the growth that the industry potentially could continue having.”

To expand on the previous comment, another stakeholder reiterated the same concern, "my biggest fear is not being able to manage the crowds of tourists. At different times of year it's much more difficult to park, to go places, to visit museums, to do anything because of the number of tourists. I think it still doesn't detract from living here but there is a balance and you can't go too far in one direction.”

Another major fear and concern amongst the stakeholder group was the chance of natural disaster, mainly hurricanes, hitting the Savannah region. Savannah is a coastal city and is susceptible to severely damaging hurricanes. Hurricanes could possible destroy an urban forest and limit tourism to a city. One stakeholder explained, "The only thing that would change anything for us would be a catastrophic event, like if we we're to have a Katrina. That would be tough for us because then not only would everyone realize the value we had in the trees, it would be a rebuilding process. We'd have to start all over again.” Another stakeholder agrees, "We have been lucky because we have not had a major hurricane come through and the reality is if we get one big storm, we lose a lot of our urban forest.” 


\section{Essence of Savannah}

There are numerous places throughout Savannah that capture the essence of the city. There is not one place that encapsulates the heart of Savannah, but rather multiple destinations throughout the city. The squares were brought up often, but not one particular square (4 of 12). One of the most popular locations revealed in this study was Forsyth Park (5 out of 12). As one stakeholder put it, "it’s like the squares but bigger and more dramatic."

Another popular spot mentioned was the walk down Bull Street from Forsyth Park to City Hall (2 out of 12). "You get a variety; you get the whole giant park with the arboretum and the trees and then you get those squares and there's a lot you can read and take in on the history in just that one corridor.” A few other places pointed out were the historic district in general (2 of 12), Washington Avenue because of the tree canopy (1 of 12), River Street (2 of 12), Daffin Park (1 of 12), the cemeteries' (1 of 12) and finally the people of Savannah were also mentioned as making it special (1 of 12). 


\section{Chapter 5. DISCUSSION}

\section{Summary}

The results of this study indicate there is a strong connection between urban forestry and sustainable tourism development. The urban forests of Savannah were established in 1733 by General James Oglethorpe when he laid out the city in a series of grids surrounding 24 squares. There are still 21 squares in existence and number 22 is currently in the process of being reconstructed.

Today, Savannah is still maintaining and preserving the urban forests of 276 years ago. Visitors come to Savannah for many reasons. It is a unique city filled with history, architecture, art galleries, festivals, and celebrities, i.e., Paula Deen, John Berendt. The urban forest is one of the significant factors attracting visitors to Savannah. Although visitors may not realize the size of the urban forest before they arrive, they will soon witness the extent of the size, care and maintenance that goes into preserving the urban forest.

Savannah is currently on the path to become a sustainable community. In addition to new wastewater systems for irrigation, converting the traffic lights to LED’s, and increasing the number of tree plantings, the city has established the sustainable committee Thrive, which will help to educate the residents of Savannah to become better stewards of the land (Cobblestone News, 2009).

Overall, the stakeholders agree that the urban forests play a large role sustainable tourism development. As one participant noted, “Savannah’s urban forest and tourism are really inextricably linked together.” Therefore, in order to sustain tourism, Savannah needs to sustain the urban forest. 


\section{Urban Forestry and Sustainable Tourism Development}

The objective of sustainability is to recognize the intertwined importance of social, economic and environmental imperatives and to find ways of contributing to all of them and strengthen the whole (Kemp, Parto, \& Gibson, 2005). As shown in Figure 1, the Venn Diagram illustrates the importance of balancing all three aspects to develop a sustainable community.

Based on the three dimensions and the scope of sustainable development, the research intended to explore if there was a connection between Savannah's urban forest and sustainable tourism development. A review of the literature and the collection of data helped build a solid foundation toward understanding the role of urban forestry in sustainable tourism development.

The results of this study support the previous literature on urban forestry, urban tourism, sustainable development and aesthetics. As is the case in Savannah, the urban forests are not limited to only the trees, wildlife, watersheds and vegetation, but they encompass all of the trees along the streets, roadways, parks, squares, public spaces, residential yards and neighborhoods, and undeveloped land. Managing urban forests are an integral part of urban community ecosystems for physiological, sociological, economic and aesthetic benefits (SAF, 2002). All of the responses from the participants confirmed that continual maintenance and preservation is necessary to sustain the urban forests in order to promote an increase in the quality of life within the community and also generate tourism.

The negative aspects of the urban forests cited by the stakeholders correlated with the literature. Maintaining an urban forest can be associated with high cost, i.e. debris removal after storms, inappropriate planting and poor management. Management practices, programs, and policies influence the cost and are essential for actions taken to enhance the urban forest and the well being of the population (Dwyer et al., 1992). 
The city of Savannah takes great pride in their urban forest and has established a department (Savannah Park and Tree Department) that is strictly responsible for preserving, maintaining and improving the urban forests of Savannah. The history of the Park and Tree Department goes back to 1896 when the Park \& Tree Commission was established to preserve the forestation and beautification of the city (City of Savannah, 2009). Savannah has also established special funds, taxes and fees to help support the sustainability of the urban forest.

However, as the literature states, the costs of planned urban forest management are outweighed by the benefits to the public and community as a whole (SAF, 2002). This was also a consensus among the stakeholders. As one participant explained, " There is a great deal of tax money that goes to the maintenance, so I guess that can be seen as a liability to the cost, but people are willing to pay that cost to have this quality of life.”

The main concern among the participants was the overdevelopment of Savannah and establishing a healthy balance of residents and tourists. According to Beatley and Manning (1997), the goals of sustainable communities is the focus on reusing already committed lands before consuming, destroying or wasting important natural and open lands. This literature is consistent with the responses of the stakeholders' fears of Savannah reaching a developmental saturation point. The results of the study also support these concerns in the urban tourism literature. If the key requirement of the sustainability of both the city and tourism is not maintaining a sense of community within the urban destination, urban tourism has the potential to self-destruct and wok against sustainability (Hinch, 1996).

Savannah currently struggles in balancing residents and visitors. Tourism is the number two economic generator in the city and a large amount of residents benefit from the tourism industry. Managing the changes that tourism inflicts on the community and weighing the costs 
and benefits will help determine the limits of acceptability as tourism continues to grow (Paskaleva-Shapira, 2007).

According to the participants, the difficulties arise for residents as they are trying to cope with the constant tour companies circling the squares in front of the homes or trying to find a place to park. The participants express concern over the parking situations. One participant explained, "One important issue is learning to deal with the numbers and where to park them and get them through our great area.” Parking is a problem in Savannah and the residents are the ones who feel the repercussions. A few examples to help alleviate the current parking issue is the development of an underground parking garage, the Downtown Transportation System (DOT), a fare free bus system, and the River Street Streetcar (Resident's Brochure, 2009). The city of Savannah needs to continuously update and revise tourism plans to help alleviate some of this conflict without compromising too many aspects of either side. However, there may not ever be a good way to appease all parties involved.

With Savannah being partially reliable on tourism as a contributor to the economy, urban development is continuous and Savannah attracts a high volume of travelers. Tourism provides opportunities to create employment and stimulate regional development (McKercher, 2003). Surprisingly, only two of the respondents mention the job markets and employee attitudes generated through tourism.

Clark et al. (1997), defined four general characteristics of urban forest sustainability: 1) sustainability is a broad, general goal; 2) urban forests primarily provide services rather than goods; 3) sustainable urban forests require human intervention; and 4) trees growing on private lands compose the majority of the urban forests. 
Savannah's urban forest embraces all four of these characteristics. First, sustainability is a broad, general goal. In Savannah, sustainability is making sure that the many things that can be done to preserve the trees and make the city prosper are being done. This includes preserving the forest, trees, and architecture, as well as preserving the culture and the uniqueness of Savannah, while at the same time continuing to attract visitors to Savannah. Preserving these places not only requires maintenance, but it requires proper management and planning and Savannah currently has several local ordinances in place to continue future preservation efforts.

Sustainability is also a balance of social, economic, and environmental elements. You must balance growth with conservation and preservation. Although the U.S. and the world are currently (2009) in an economic downturn and there has been a decline in tourism numbers, Savannah's economy is still viable because it relies on many industries to sustain profitability. Developers are presently building hotels, restaurants and shops and the city is in the process of restoring Ellis Square.

Second, urban forests primarily provide services rather than goods. The urban forest provides numerous positive ecological, environmental and social experiences. Urban forests reduce storm water runoff, reduce energy consumption and provide social and psychological well being to the community (Clark et al., 1997). Some visitors come to Savannah to view historic architecture and others come to see the live oak trees draped in Spanish moss. The commonality is that everyone benefits from the urban forest. History, culture, and experience help further a person's appreciation and understanding of a place (Bell, 1999). The responses from the stakeholders also support the aesthetic literature as it relates to sustainability. The squares are aesthetically appealing and attractive to both residents and visitors. 
Third, sustainable urban forests require human intervention. The city of Savannah’s Park and Tree Department is responsible for the maintenance of all the trees and squares in the public right of way. Their job is to effectively manage these resources, which in turn can affect the tourism industry. Visitors are not going to continue to visit a city lined with decaying trees and dilapidated resources.

However, the Park and Tree Department is not the only unit involved in maintaining the urban forest. All of the residents, employees and visitors are accountable for preserving the urban forests and being good stewards of the land. There are many behaviors people can exhibit to help protect the urban forest, i.e. no littering, no vandalism. The whole community needs to be responsible for sustaining the urban forest.

Finally, trees growing on private lands compose the majority of urban forests. The urban forest of Savannah is not limited to the squares and parks, but it includes all the trees located on private property. One of the ways to preserve the trees is through continuous planting by the city and private business owners. The tree points are another effective way to ensure the future of the urban forest. Any new development in the city has to adhere to this policy. Forest sustainability is not only the responsibility of the city of Savannah, but again it is the responsibility of the community. The results suggest that visitors are more attracted to aesthetically pleasing surroundings and the trees in front of a business will likely draw a larger crowd. This is inferred through the aesthetic literature that reiterates the fact that urban forest landscape aesthetics are planned and managed based on perceptions and preferences (Gobster, 1999; Ewald, 2001).

Throughout the interviews, the stakeholders gave many explanations for the importance and connections of Savannah's urban forest and tourism industry. However, not one of the participants mentioned the 2008 development of the Thrive initiative. This is interesting since 
Thrive has consolidated all of the previous sustainable initiative programs, as well as implemented new programs. It may be possible that the participants are not yet aware of the Thrive possibilities, which would mean the sustainability message in Savannah is not being heard.

\section{Conclusions}

The urban forest of Savannah is important to their sustainable tourism development. In order to sustain tourism, Savannah must also maintain the beauty and attractiveness of the urban forest. Savannah is currently on the path to developing a sustainable tourism community. The city is still working on finding a balance between all three aspects of the sustainable diagram: social, economic, and environmental, but it is not far off. The overall environmental, social and economic benefits of the urban forest promote and support the main principles of sustainable development. Savannah's planning and management practices associated with the urban forest and tourism acknowledge the ecological limits. However, there is still a genuine concern among the stakeholders' for the possibility of over development.

Preservation of the natural and built environment is a key component when establishing tourism and urban forestry planning and policy development. Therefore, Savannah’s efforts are focused on the restoration and regeneration of the current resources. Through this preservation, Savannah seeks to improve the quality of life for all who live and visit the city. The numerous festivals and recreational activities can be seen throughout the parks and squares. By instituting the importance of quality of life, Savannah also recognizes the importance of place. Without a sense of belonging or attachment to an area, there would be a decrease in quality of life.

With the development of recent technologies to provide a more efficient and environmentally friendly existence, Savannah is currently implementing integrative and holistic 
solutions to social and environmental problems. For example, more efficient irrigation systems in the squares, transferring state vehicle to biodiesel, and providing more public transportation to help reduce emissions and parking problems. By implementing these solutions, Savannah is implying a new ethical posture, which will moderate the consumption and overuse of resources and help develop more effective planning strategies.

The diversity and uniqueness of Savannah promotes an equitable and just destination. The variety of resources is what attracts people to Savannah. Continuing to promote this diversity is a strength that supports sustainability. Again, it is the combination of these resources that also stresses the importance of community. Both the residents and tourists of Savannah are currently involved in maintaining these resources. Through the variety of taxes and fees, all contribute to the overall well being of the city. Also, the residents are sometimes involved in planning processes. For instance, the reconstruction of Ellis Square permitted the residents to take part in planning through first passing a tax to build the square and second attending meeting to vote on the design and discuss revisions (Personal Communication, July 31, 2009).

Finally, Savannah's ability to reflect and promote a full-cost accounting of the social and environmental costs of public and private decisions is recognized. The people of Savannah are aware of the costs of maintaining the available resources and do plan accordingly. Again, the ordinances, zoning laws, taxes, and fees are assessed to preserve the urban forest and the tourism industry.

The only negative aspect of Savannah's sustainable future is the issue of vandalism within the historic district, which leads to an unpleasant environmental, economic and social setting. Vandalism can damage or even kill a tree or shrub, which in turn cost the city extra money in the maintenance or removal of the tree. There is also the chance for graffiti on statues 
and monuments throughout the historic district. Consequently, this vandalism leads to an unattractive visual setting and may reduce the attractiveness of the city to residents and visitors.

One solution to this problem could be an increased presence of authority in the more popular parks and squares in the historic district. Additional law enforcement, especially in the evening/ night hours may help deter graffiti vandalism. Another solution to this problem could be the addition of cameras strategically set up throughout the main parks or squares that see the highest amount of vandalism. With the large canopy cover, the camera placement can be discreet and not affect the aesthetic beauty of the park. However, it may still be difficult to pin point and catch the vandal's after the fact. As for the busses or children that accidentally break tree limbs, it would be complicated to assign responsibility for their actions.

As the city continues to grow and newer, efficient technologies are developed, Savannah will be a good example of how to build a sustainable community, one that balances tourism and growth with the support of the residents within the community. There are still issues of concern that need to be reviewed. For example, over development and stability among the residents and tourist is still uncertain. The residents recognize the importance of tourism, yet they fear too much tourism.

\section{Suggestions for Future Research}

During this study, the economic recession played a role in the decline of tourism in Savannah. It would be interesting to see the different responses during a period of economic prosperity. Revisiting Savannah once the economy rebounds could possibly lead to a different set of results. Since the idea of building a sustainable community is a rather recent goal of many cities, it would also be interesting to revisit this study in five to ten years and see how Savannah has progressed. 


\section{APPENDICES}

\section{Appendix A}

The following is a copy of the Stakeholder Questionnaire:

1. What are the most important issues facing Savannah’s tourism industry today?

2. A. How would you define sustainability and the role it plays in tourism development?

B. How do you view urban forestry as a contributor to sustainable communities?

3. What are the positive and negative contributions of urban forests in Savannah?

4. What are the economic impacts of developing and maintaining an urban forest? What are the environmental and social impacts?

5. What role do trees play in attracting visitor's to Savannah?

6. In developing a tourism plan for Savannah, what objectives are considered the most viable to implementing and managing a successful outcome?

7. What are your wishes, dreams, and hopes for the future of Savannah's tourism industry?

8. What are your fears and concern's for Savannah's tourism future?

9. What place do you think is most special and captures the essence of Savannah? 


\section{Appendix B}

The participants included individuals from the following departments, offices, and organizations:

- Chatham County Internal Audit Department

- $\quad$ City of Savannah Park and Tree Department

- $\quad$ City of Savannah Leisure Services Bureau

- City of Savannah Mayor’s Office

- Georgia Urban Forestry Council

- Local Savannah Tourism Operator

- Savannah Convention and Visitor's Bureau

- Savannah Tourism and Film Services

- Savannah Tree Foundation

- $\quad$ USDA Forest Service, Southern Region 


\section{REFERENCES}

Adams, W.M. (2006). The future of sustainability: Re-thinking environment and development in the twenty-first Century. Report of the IUCN Renowned Thinkers Meeting, January, 2006, Zurich, Switzerland. Retrieved April 21, 2009 from http://cmsdata.iucn.org/downloads/iucn_future_of_sustanability.pdf

Alliance for Community Trees (ACT) (2008). The value of trees. Retrieved November 10, 2008 from http://actrees.org/files/Resources/ValueOfTrees_FactSheet.pdf

Asprogerakas, E. (2007). City competition and urban marketing: The case of tourism industry in Athens. Tourismos: An International Multidisciplinary Journal of Tourism, 2(1), 89114.

Averill, J.R., Stanat, P., More, T.A. (1998). Aesthetics and the environment. Review of General Psychology, 2(2), 153-174.

Barker, R. (n.d.). The importance of tree risk management plans. Georgia Urban Forest Council. Retrieved April 20, 2009 from http://www.gufc.org/resources/best-management-practices/

Beatley, T. \& Manning, K. (1997). The ecology of place: Planning for environment, economy, and community. Washington, DC: Island Press

Bell, S. (1999). Landscape: Pattern, Perception and Process. In S.R.J. Sheppard \& H.W. Harshaw (Eds.), Forests and Landscapes: Linking Ecology, Sustainability, and Aesthetics (pp. 125-146). Wallingford, UK: CABI Publishing.

Bourassa, S.C. (1992). Public welfare and the economics of landscape aesthetics. Landscape and Urban Planning, 22, 31-39. 
Bramwell, B. (1998). User satisfaction and product development in urban tourism. Tourism Management, 19 (1), 35-47.

Bulcao, L., Ribeiro, L., Arsenio, P., \& Abreu, M.M. (2004). The protection of landscape as a resource: Case study - Monte da Guia protected area. Management of Environmental Quality, 15 (1), 48-54.

Butler, R. \& Dodds, R. (2003, June). Governance and sustainability of urban tourism: Global challenges. SUT Governance Project Conference, Heidelberg, Germany.

Center for Urban Forest Research, Pacific Southwest Research Station. (2008). US Forest Service, Davis, CA. Retrieved October 21, 2008 from http://www.fs.fed.us/psw/programs/cufr/whatwedo/

Citizens’ Report, City of Savannah’s Public Information Office. (2009, April). Thrive: Savannah’s sustainability plan. Retrieved September 22, 2009 from http://www.savannahga.gov/cityweb/SavannahGaGOV.nsf/0/b1aa5618251af7908525733 600578e90/\$FILE/CitizensReport_April2009.pdf

City of Savannah. (2009). Park and Tree Department. Retrieved September 22, 2009 from http://www.ci.savannah.ga.us/cityweb/p\&tweb.nsf/950e01f292e02b9c852568ab00686f30 /64b3ed817cd0a52885256c5a004a73b9?OpenDocument

Clark, J.R., Matheny, N.P., Cross, G. \& Wake, V. (1997). A model of urban forest sustainability. Journal of Arboriculture, 23(1), 17-30.

Clarke, J. (1997). A framework of approaches to sustainable tourism. Journal of Sustainable Tourism, 5(3), 224-233.

Cobblestone News. (2009, Summer). City of Savannah. 
Daniel, T. (2001). Whither scenic beauty? Visual landscape quality assessment in the $21^{\text {st }}$ century. Landscape and Urban Planning, 54, 267-281.

Dwyer, J.F., Nowak, D.J., \& Noble, M.H. (2003). Sustaining urban forests. Journal of Arboriculture, 29(1), 49-55.

Dwyer, J.F., Nowak, D.J., Noble, M.H. \& Sisinni, S.M. (2000). Connecting people with ecosystems in the $21^{\text {st }}$ century: An assessment of our nation's urban forests. Gen. Tech. Rpt. PNW-GTR-490. USDA Forest Service, Pacific Northwest Research Station, Portland, OR.

Dwyer, J.F., McPherson, E.G., Schroeder, H.W., \& Rowntree, R.A. (1992). Assessing the benefits and costs of the urban forest. Journal of Arboriculture, 18(5), 227-234.

Elmendorf, W.F., Crotone, V.J., \& Mullen, J.T. (2003). Trends in urban forestry practices, programs, and sustainability: Contrasting a Pennsylvania, U.S. Study. Journal of Arboriculture, 29(4), 237-248.

European Commission. (2000). Towards quality urban tourism: Integrated quality management of urban tourist destinations (ISBN 92-828-7839-2). Luxemburg: Office for Official Publications of the European Communities. Retrieved June 15, 2009 from http://ec.europa.eu/enterprise/library/lib-tourism/iqm-summary/urban_en.pdf

The Essential Guide to Savannah (1998). Savannah history. Retrieved November 10, 2008 from http://www.ego.net/us/ga/sav/history/index.htm

Ewald, K.C. (2001). The neglect of aesthetics in landscape planning in Switzerland. Landscape and Urban Planning, 54, 255-256.

Galdini, P. (2007). Tourism and the city: Opportunity for regeneration. Tourismos: An International Multidisciplinary Journal of Tourism, 2(2), 95-111. 
Garin-Munoz, T. (2004). Madrid as a tourist destination: Analysis and modelization of inbound tourism. International Journal of Tourism Research, 6, 289-302.

Gobster, P. (1999). An ecological aesthetic for forest landscape management. Landscape Journal, 18(1), 54-64

Hinch, T.D. (1996). Urban tourism: Perspectives on sustainability. Journal of Sustainable Tourism, 4(2), 95-110.

Hunter, C. (2002). Sustainable tourism and the touristic ecological footprint. Environment, Development, and Sustainability, 4, 7-20.

Institute for Sustainable Communities (2008). Retrieved on October 21, 2008 from http://www.iscvt.org

Jamieson, W. \& Sunalai, P. (2002). The management of urban tourism destination: The cases of Klong Khwang and Phimai, Thailand. UMP- Asia Occasional Paper No. 56.

Kemp, R., Parto, S. and Gibson, R.B. (2005). Governance for sustainable development: Moving from theory to practice. International Journal of Sustainable Development, 8(1/2), 12-30.

Kiernan, M., Kiernan, N.E., \& Goldberg, J. (2003). Using standard phrases in qualitative interviews. Tipsheet \#69, University Park, PA: Penn State Cooperative Extension. Konijnendijk, C.C. (2008). The forest and the city: The cultural landscape of urban woodland. The Netherlands: Springer.

Konijnendijk, C.C., Sadio, S., Randrup, T.B., \& Schipperijn, J. (2004). Urban and peri-urban forestry in a development context-strategy and implementation. Journal of Arboculture, 30(5), 269-276.

Kreag, G. (2001). The impacts of tourism. Minneapolis, MN: Minnesota Sea Grant. 
Kuo, F.E. \& Sullivan, W.C. (2001). Coping with poverty: Impacts of environment and attention in the inner city. Environmental Behavior, 33(1), 5-34.

Law, C.M. (1993). Urban tourism: Attracting visitors to large cities. London, UK: Mansell Publishing Limited.

Law, C.M. (2001). Urban tourism: The visitor economy and the growth of large cities. London, UK: Continuum

Long, L.W. (1989, September). Continuous audience response technology and survey methods: New research methods and an application. Speech/Meeting Papers retrieved on November 18, 2008 from http://www.eric.ed.gov/ERICWebPortal/recordDetail?accno=ED331744 - 25k

Lothian, A. (1999). Landscape and the philosophy of aesthetics: Is landscape quality inherent in the landscape or in the eye of the beholder? Landscape and Urban Planning, 44, 177-198.

McKercher, B. (2003, November). Sustainable tourism development-guiding principles for planning and management. Paper presented at the National Seminar of Sustainable Tourism Development, Bishkek, Kyrgystan.

Murphy, P.E. (1992). Urban tourism and visitor behavior. The American Behavioral Scientist, 36 (2), 200-211.

National Commission on the Environment (1993). Choosing a sustainable future. Washington, DC: Island Press.

New Georgia Encyclopedia (NGE) (2008). Savannah city plan. Retrieved November 10, 2008 from http://www.georgiaencyclopedia.org/nge/Article.jsp?id=h-2547 
Notarstefano, C. (2007, November). European sustainable tourism: Context, concepts, and guidelines for action. Paper presented at the Global Jean Monnet Conference: The European Union and World Sustainable Development, Brussels, Belgium.

O’Connor, T. (n.d.). Qualitative Social Science Research Methodology. (n.d.). Retrieved February 21, 2008 from http://faculty.ncwc.edu/toconnor/308/3081ect09.htm

Patton, M.Q. (2002). Qualitative Research and Evaluation Methods ( $3^{\text {rd }}$ ed.). Thousand Oaks, CA: Sage Publications.

Parsons, R. \& Daniel, T. (2002). Good looking: In defense of scenic landscape aesthetics. Landscape and Urban Planning, 60, 43-56

Paskaleva-Shapira, K.A. (2007). New paradigms in city tourism management: Redefining destination promotion. Journal of Travel Research, 46, 108-114.

Pearce, D.G. (2001). An integrative framework for urban tourism research. Annals of Tourism Research, 28 (4), 926-946.

Pierskalla, C.D., Saunders, K.E., McGill, D.W., \& Smaldone, D.A. (2007). Forest landscape assessment: The effects of pre-experience education on public perception of scenic beauty. Proceedings form the Northeastern Recreation Research Symposium, GTRNRS-P-23, 70-76.

Research \& Budget. (2008, March). City Financials, 1(1), p1-8. Retrieved on September, 22, 2009 from http://www.ci.savannah.ga.us/CityWeb/RB_Budget.nsf/0/ec1b033c6862920c852574340 06284e3/\$FILE/City\%20Financials.pdf

Resident’s Brochure. (2009, Summer). Downtown Neighborhood Association: Savannah, GA. 
Ruetsche, J. (2006, May). Urban tourism: What attracts visitors to cities? University of Wisconsin-Extension, Let’s Talk Business e-newsletter, 117. Retrieved June 14, 2009 from http://www.uwex.edu/ces/cced/downtowns/ltb/lets/LTB0506.pdf

Savannah Area Convention \& Visitors Bureau (CVB) (2008). Our history so far. Retrieved November 10, 2008 from http://www.savannahvisit.com/info.asp

The Scottish Parliament-The Information Center (SPIC) (2002, August). Urban tourism and dispersal. Briefing produced for the Enterprise and Lifelong Learning Committee, Scotland. Retrieved October 21, 2008 from http://fama2.us.es:8080/turismo/turismonet1/economia\%20del\%20turismo/turismo\%20de \%20ciudades/URBAN\%20TOURISM\%20AN\%20DISPERSAL.PDF

Society of American Foresters. (2007). Urban forestry. Bethesda, MD.

Stemler, S. (2001). An overview of content analysis. Practical Assessment, Research \& Evaluation, 7 (17). Retrieved July 17, 2009 from http://pareonline.net/getvn.asp?v=7\&n=17

Swarbrooke, J. (1999). Sustainable tourism management. Wallingford, UK: CABI Publishing. Tyrvainen, L \& Lofstrum, I. (1998, October). Ecological and aesthetic values in management of urban forests. AISF-EIF International Conference on Forest Management in Designated Conservation and Recreation Areas, Florence, Italy.

Tyrvainen, L, Silvennoinen, H, \& Kolehmainen, O. (2003). Ecological and aesthetic values in urban forest management. Urban Forestry \& Urban Greening, 1(3), 135-149.

Urban tourism (n.d.). Dictionary.com's 21st Century Lexicon. Retrieved October 21, 2008 from http://dictionary.reference.com/browse/urban tourism 
Wikipedia (2009). Squares of Savannah. Retrieved April 21, 2009 from http://en.wikipedia.org/wiki/File:SquaresOfSavannah.jpg\#file

World Commission on the Environment and Development (WCED) (1987). Our common future. Oxford, UK: Oxford University Press.

World Tourism Organization (WTO) (2004). Retrieved October 21, 2008 from http://www.unwto.org/sdt/mission/en/mission.php?op=1

World Tourism Organization (WTO) (2009, October). Retrieved October 21, 2009 from http://www.unwto.org/index.php 